\title{
Strategic Responses to New Zealand-China Free Trade Agreement: A Case Study of New Zealand Natural Health Products Industry
}

by

\author{
Jiang Chang
}

A thesis submitted in fulfillment of the requirements for the degree of Master of Commerce and Administration in International Business

May 2009

School of Marketing and International Business

Victoria University of Wellington 


\section{Abstract}

The rise of global consumption, as well as technological innovation in transportation and telecommunications, have increased international exchange of goods, services and factors of production. Economic globalization in terms of production and markets has been accompanied by an unprecedented intensification of economic and financial linkages within geographic regions. The world economy is shifting towards greater regional economic integration.

As open and dynamic economies, New Zealand and China heavily rely on international trade and investment to stimulate economic growth. Strengthened international linkages and improved access to markets are major economic strategies for both countries. As they have been committed to building up longstanding and healthy bilateral trade and economic partnerships, these two countries signed a free trade agreement (FTA) that aims to liberalize and facilitate trade in goods, services and investment, and improve the business environment and strengthen cooperation in a wide range of economic areas. From the perspective of New Zealand's businesses, the FTA will not only improve the business environment, and open up market access opportunities, but it will also pose threats. To take advantage of these opportunities, neutralize threats, and consequently achieve a stronger market position in the Chinese marketplace, New Zealand's businesses must strategically respond to the fastchanging environment arising from the FTA.

Due to the special meaning of the FTA to New Zealand's economic growth and the significance of the Chinese market to New Zealand's businesses operating in China, it is important to explore how New Zealand's firms perceive the New 
Zealand-China FTA; and what strategic decisions and adjustments they have made or they are going to make in response to shifts in the business environment arising from the FTA. Besides several studies with limited empirical evidence were conducted at the macro-economic level by some of interested groups such as New Zealand Ministry of Foreign Affairs and Trade during the FTA negotiations, little research has been conducted to examine the impact of the New Zealand-China FTA on New Zealand individual companies' business strategic performance.

Building on case studies of two representative companies in the New Zealand natural health products industry, this study aims to discover the nature of salient companies under the New Zealand-China FTA and to ascertain what particular patterns of strategy and performance these companies will adopt in response to trade liberalization. The findings of this study suggest that: 1) With the New Zealand-China FTA, the Chinese fast-growing market is typical of the mix of the opportunities and challenges facing New Zealand's businesses. The FTA provides them with a strong incentive to undertake strategic adjustments for further development in the Chinese market. 2) Strategic adjustments made by a firm depend upon the nature of its firm-specific advantages and country-specific advantages, as well as its existing competitive advantages. Firms that are able to secure their resources and capabilities necessary to exploit opportunities and counter threats are more likely to gain international competitive advantages; 3) Small firms with limited resources and capabilities are more likely to engage in the formation of strategic alliances in order to strengthen their competitive positions both domestically and internationally. 


\section{Acknowledgements}

I would like to take this opportunity to express my gratitude and sincere thanks to my supervisors Dr. Joanna Scott-Kennel and Dr. Val Lindsay. I do appreciate their encouragement, support and professional guidance throughout the research process. My thanks also go to the School of Marketing and International Business of Victoria University of Wellington. I received substantial support and assistance from the school over my postgraduate years.

Special gratitude must be extended to all people who contributed to the completion of this research, particularly, the interviewees from Company A and Company B. Without their willingness to participate and commitment to the outcomes of this research, I would not have completed my thesis successfully.

Lastly, I want to express my heartfelt gratitude and love to my parents. The deepest appreciation goes to them for their unfailing love and support during my life. I would not be where I am today without their nurturance. 


\section{Table of Contents}

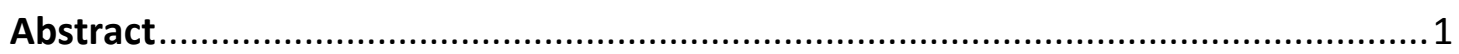

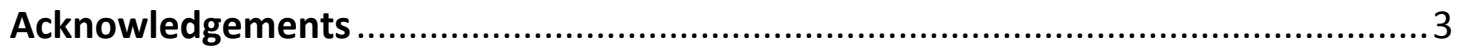

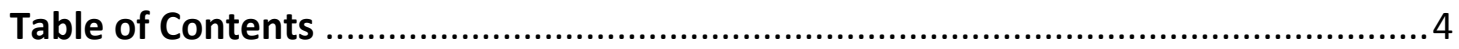

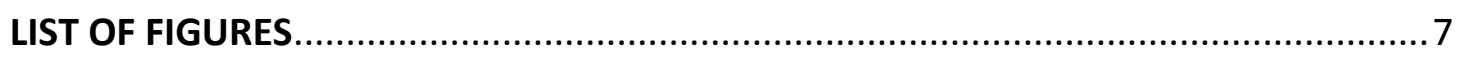

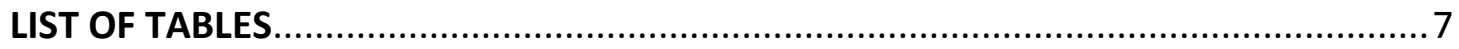

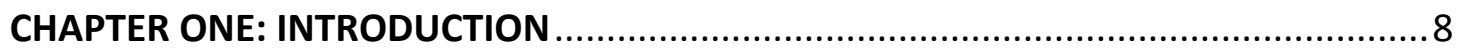

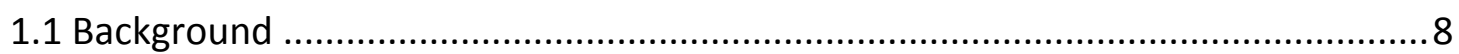

1.2 Overview of New Zealand-China FTA............................................................. 10

1.3 Overview of New Zealand Natural Health Products Industry under the FTA........12

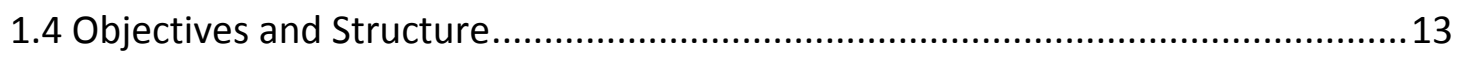

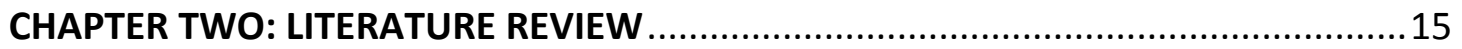

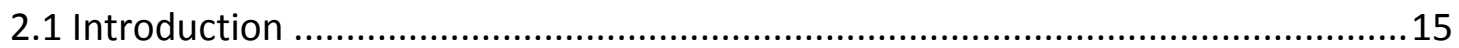

2.2 Regionalization in the World Economy............................................................. 16

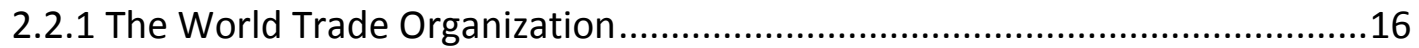

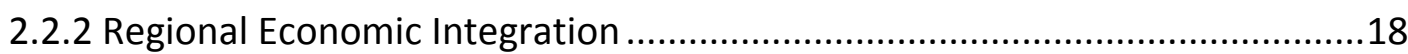

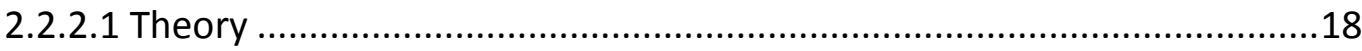

2.2.2.2 Era of Regional Economic Integration.................................................19

2.2.3 Characteristics and Development of Free Trade Agreements......................20

2.2.4 Trade Liberalization in Asia-Pacific ................................................................22

2.3 International Strategic Management and Free Trade Agreement ........................23

2.3.1 Business Environment under the Free Trade Agreement ............................25

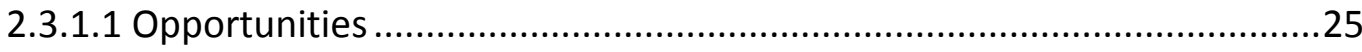

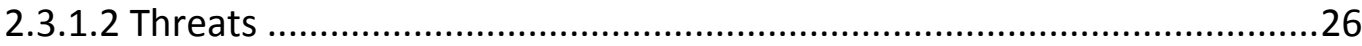

2.3.2 Development of International Competitiveness ........................................27

2.4 Conceptual Framework Development ...............................................................29

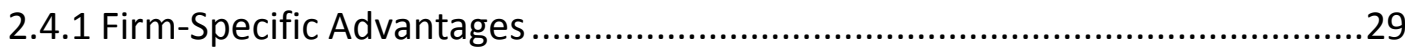

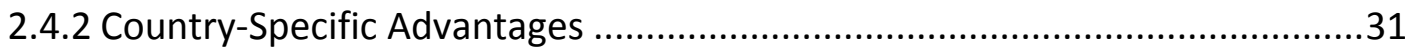

2.4.3 Competitive Strategy Framework …..........................................................33

2.5 The Bilateral Relationship Development between New Zealand and China ..........36

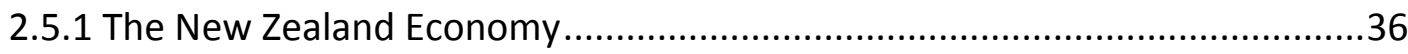

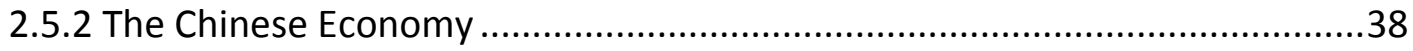


2.5.3 Bilateral Economic and Trade Relations between New Zealand and

China

2.6 Impact of New Zealand-China FTA on New Zealand Natural Health Products Industry .45

2.6.1 The Background of the New Zealand Natural Health Products Industry .......45

2.6.2 Trends and Potentials in the Chinese Natural Health Products Market.........47

2.6.3 SWOT analysis on New Zealand Natural Health Products Industry under

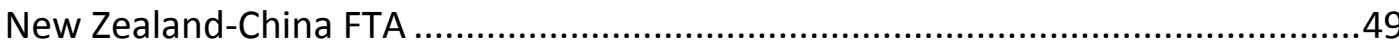

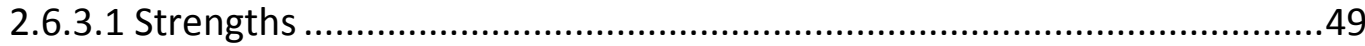

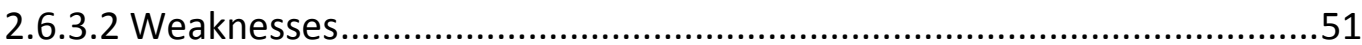

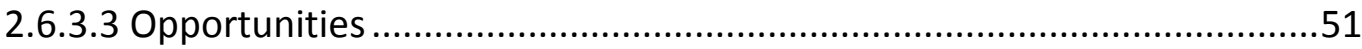

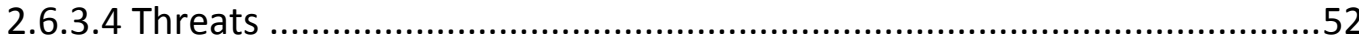

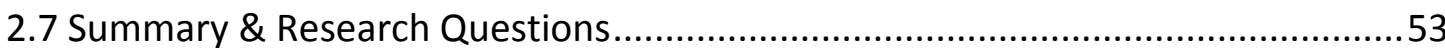

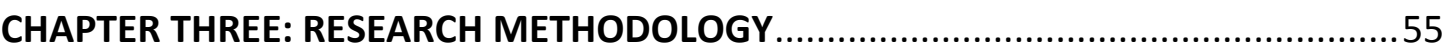

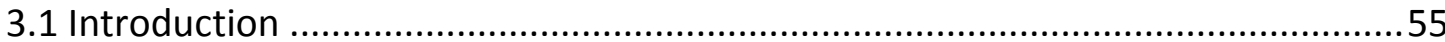

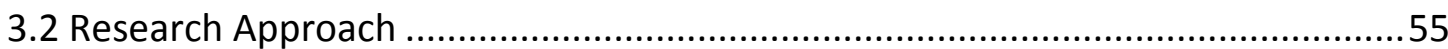

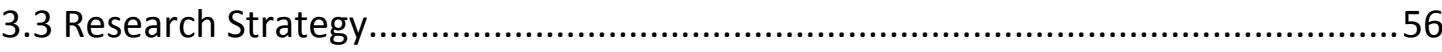

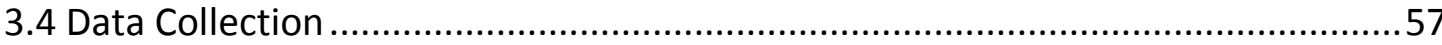

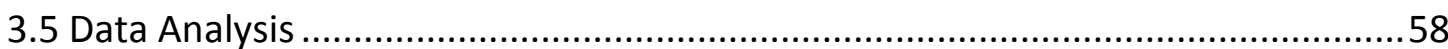

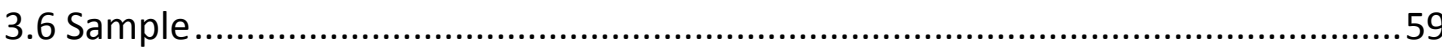

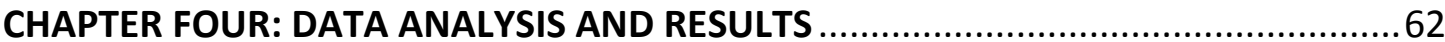

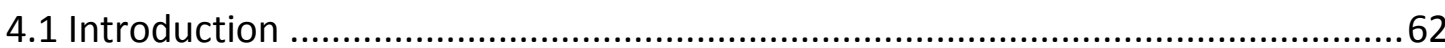

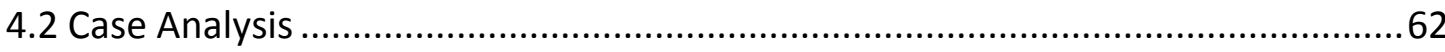

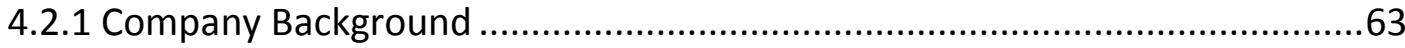

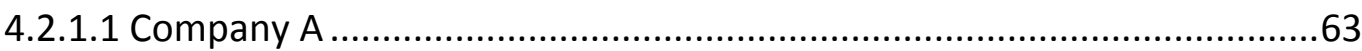

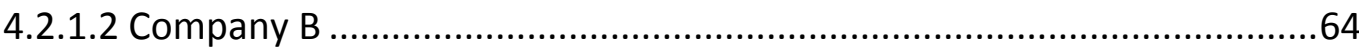

4.2.2 Country Specific Advantages facing Company A \& Company B......................66

4.2.3 Strategic Adjustments by Company A \& Company B....................................69

CHAPTER FIVE: DISCUSSION, IMPLICATIONS \& RECOMMENDATIONS ….................77

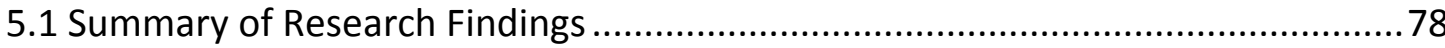

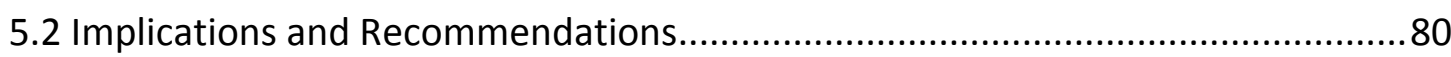

5.2.1 Managerial Implications and Recommendations .....................................80 


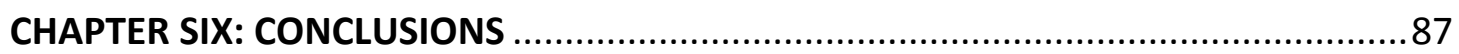

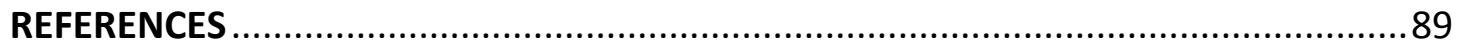

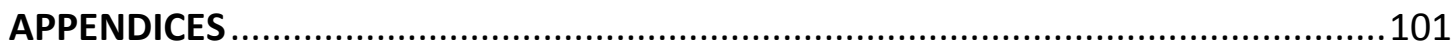

Appendix A: SWOT analysis of NZ natural health products industry........................101

Appendix B: Participant Information Sheet ...........................................................102

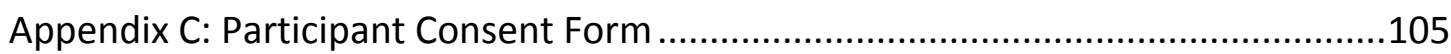

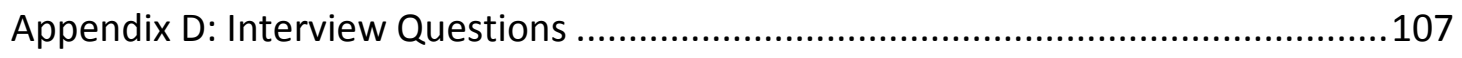




\section{LIST OF FIGURES}

Figure 2.1: All RTAs notified to the GATT/WTO (1948-2007), by year of entry into

force 20

Figure 2.2: Notified RTAs in force, as of December 2006, by type of agreement .......21

Figure 2.3: RTAs signed, under negotiation and proposed, as of December 2006,

by type of agreement. .21

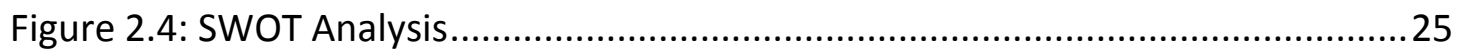

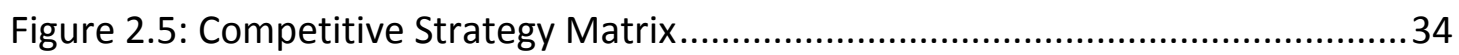

Figure 2.6: Reducing Duties on Total NZ Exports to China .....................................4 44

Figure 4.1: Strategic Adjustments by Company A and Company B

\section{LIST OF TABLES}

Table 2.1: Major trade arrangements in Asia-Pacific.

Table 2.2: New Zealand Merchandise Trade with Major Trading Partners (Year ended June 2008) 37

Table 2.3: China's Merchandise Trade, 1979-2006 (US\$ billion). .39

Table 2.4: Contracted and Actual FDI in China, 1979-2006 (US\$ billion) 40

Table 2.5: The Complementary Relationship between New Zealand and China (2007) 


\section{CHAPTER ONE: INTRODUCTION}

\subsection{Background}

The world economy has experienced fundamental change over the past few decades. The rise of global consumption, as well as technological innovation in transportation and telecommunications, have increased international exchange of goods, services and factors of production. Economic globalization in terms of production and markets has been accompanied by an unprecedented intensification of economic and financial linkages within geographic regions (Armengol et al., 2005). While the global trading system under the World Trade Organization (WTO) remains the basic framework for the conduct of economic interdependence among countries, the emergence of world-scale regional trading groupings such as the European Union (EU), the Asia-Pacific Economic Cooperation (APEC), and the Southern Common Market (MERCOSUR), as well as a variety of country-level trade agreements such as New Zealand-China Free Trade Agreement have been shifting the global economy towards greater regional economic integration.

Reflecting the diversity of economies and their histories, regional integration follows markedly different patterns that vary widely in depth and breadth (Armengol et al., 2005). From least integrated to most integrated, for example, there are free trade agreements (FTA), customs unions, common markets, economic unions, and political unions (Hill, 2005). Of these various types, free trade agreements (FTAs) appear to be most actively pursued by numerous countries at different stages of economic development in the recent past, due to 
its comparable advantages in terms of speed, scope and flexibility. In particular, an obvious attraction of an FTA between two or more countries is that members can easily and quickly access to markets of other member countries compared with more global trade agreements negotiated in the context of WTO multilateral rounds. Furthermore, an FTA enables member countries to be more flexible in terms of desired trade policy scope and therefore require lower degree of policy coordination amongst participating countries (Fiorentino et al., 2006).

Since 2000, there has been a proliferation of FTAs around the world. The WTO reports about 300 FTAs or regional free trade agreements signed or under negotiation globally (NZMFAT, 2007). The significance of this phenomenon has drawn great attention from scholars, economists, and policymakers since it will ultimately influence the nature of international trade relations, domestic policy choices, and behaviour of the operating actors (Fiorentino et al., 2006). More importantly, rapid changes in the global business environment have revolutionized the tasks facing managers of international companies in any given industries. They must learn to react efficiently and effectively to these environmental changes in an attempt to survive and thrive in today's more complex business environment. Compared to economic and political interests, however, few studies consider the micro-level processes of firms' strategic adjustments in response to trade liberalization. With this in mind, this research considers strategic decisions made by New Zealand's businesses in adjusting to the New Zealand-China FTA. 


\subsection{Overview of New Zealand-China FTA}

As open and dynamic economies, New Zealand and China heavily rely on international trade and investment to stimulate economic growth. Strengthened international linkages and improved access to markets become major economic strategies for both countries (NZMFAT, 2004).

New Zealand and China have a longstanding and healthy bilateral relationship with regard to economic cooperation, education, tourism, and human resource exchange. As members of the World Trade Organization (WTO) and the AsiaPacific Economic Cooperation Forum (APEC), these two countries have a long history in working together to strengthen the multilateral system and promote regional economic development (NZMFAT, 2004). Under such favourable circumstances, the trading relationship between New Zealand and China has been deepened in recent years, and ultimately a Free Trade Agreement between two countries was signed on $7^{\text {th }}$ of April 2008.

The agreement is significant for both economies in several respects. With implementation of the New Zealand-China FTA, New Zealand became the first country in the developed world to conclude a comprehensive free trade agreement with China. This is also New Zealand's biggest bilateral trade deal since it established the closer economic relations trade agreement with Australia 25 years ago (NZMFAT, 2008a). The agreement will liberalize and facilitate trade in goods, services and investment between two countries. It also contains measures to improve the business environment and promote cooperation between two countries in a broad range of economic areas. Given the complementary 
nature of two economies, the New Zealand-China FTA represents a significant milestone in the maturity of the relationship (NZMFAT, 2008b).

In some sense, the bilateral trade liberalization with China is a significant achievement for the New Zealand economy. As a trading nation, New Zealand's economic growth depends to a large extent on its competitiveness in selling goods and services to foreign markets, especially the markets with huge potential for internationalizing. The New Zealand-China FTA provides an excellent opportunity for New Zealand's businesses to operate in the world's fastest growing market, reflected by the population of 1.3 billion and the rapid extension of the middle class (NZMFAT, 2008a).

From the perspective of New Zealand's businesses, the FTA implies a major business environmental change for their operations. As an emerging economy, China represents both opportunities and challenges for New Zealand's firms to expand internationally. On the one hand, the elimination of trade barriers coupled with further cooperation in a broad range of economic areas such as intellectual property and human resources present New Zealand's firms with enhanced market penetrating opportunities in China. And securing preferential access to China's economy has the potential to deliver significant gains to these firms (NZMFAT, 2008b).

However, the vast differences in history, geography, culture, politics and economic structure between two nations also bring fresh challenges to New Zealand's managers. Combined with other issues such as increased competition 
as a result of more market openness, it can throw obstacles in the path of New Zealand's businesses operating in the Chinese market. Therefore, the New Zealand-China FTA influences organizational and strategic performance of individual firms, and force strategic adjustments of industries that are most affected by the agreement (Rugman \& Gestrin, 1993). In order to take advantage of the FTA and achieve market growth in China, New Zealand's businesses must be well positioned and equipped to maximize these opportunities and minimize the obstacles facing them in the new trading environment arising from the New Zealand-China FTA (NZTE, 2008).

\subsection{Overview of New Zealand Natural Health Products Industry under the FTA}

Among various industries in New Zealand, the natural health products industry stands to be influenced more significantly by the New Zealand-China FTA for several reasons. First of all, China recognises the importance of biotechnology in general, and sees as beneficial the creative application of biotechnology to areas such as healthcare and food production in particular. China is one of the top five markets for the New Zealand's natural health products exports. With the huge market potential for health products, the FTA will provide a greater opportunity for New Zealand's natural health products companies to expand in the Chinese market. Moreover, New Zealand's manufactured products exported into China have recently faced very high tariffs, which increase the price to local consumers and therefore limited the market growth in China. Given the phased elimination of tariffs for natural health products planned under the FTA rules, the New Zealand natural health products exporters will see a significant reduction in the 
cost of trading with China. The lower production costs and the prices of the final manufactured natural health products will be beneficial for producers and consumers in both countries (Briar, 2004; NZMFAT, 2008a).

\subsection{Objectives and Structure}

Due to the special meaning of the FTA to New Zealand's economic growth and the significance of the Chinese market to the businesses in the New Zealand natural health products industry, it is important to explore how New Zealand's natural health products companies perceive the New Zealand-China FTA; what strategic decisions and adjustments they have made or they are going to make in response to shifts in business environment arising from the FTA. Apart from several studies which were undertaken at a broad level by some interested groups such as the New Zealand Ministry of Foreign Affairs and Trade during the FTA negotiations, little research has been conducted to examine the impact of the New Zealand-China FTA on the New Zealand individual companies' business strategic performance.

In order to fill up this gap, this research is being conducted to identify and analyse strengths and weaknesses in the New Zealand natural health products sector; opportunities/potential and challenges/threats facing the companies in the sector, as well as their strategic responses to the New Zealand-China FTA. Building on the case of two leading companies in New Zealand's natural health products industry, the study aims to discover the nature of salient companies under an FTA and to ascertain what the particular patterns of strategy and performance the companies will adopt in response to trade liberalization. The 
findings of this research will be of great value to academic and government communities, and especially assist New Zealand's businesses in developing their own capabilities to operate in China's complex, diverse and fast-changing business environment.

The study is structured as follows. Chapter one provides an overview of the New Zealand-China FTA, and the New Zealand natural health products industry, as well as a background of the world's free trade development. Then, the objectives and structure of this study are established. Chapter two begins with a broad background of regionalization in the world economy, which is symbolized by the recent rash of FTAs. It then moves on to an evaluation of the literature of international strategic management in the context of trade liberalization. This is following by the development of a conceptual framework. The chapter also reviews the bilateral trade relationship between New Zealand and China, and discusses the impact of the New Zealand-China FTA on New Zealand's natural health products industry. Chapter three describes the research methodology along with explanations of data collection and analysis techniques and the sample. In chapter four, the procedures and results of the case analysis are presented. Chapter five discusses the research findings and sets out the implications and recommendations for both practitioners and researchers. Finally, in chapter six, the paper ends with a summary of the overall study. 


\section{CHAPTER TWO: LITERATURE REVIEW}

\subsection{Introduction}

As the world economy has been moving speedily toward regional economic integration, two apparently inconsistent trends in this movement can be detected.

On the one hand, the multilateral trading system represented by the World Trade Organization (WTO) remains the basic framework for the conduct of economic relations between countries. On the other hand, countries are turning to regional trade agreements (RTAs) at either bilateral or multilateral level to pursue trade and investment liberalization objectives (Pal, 2004). As they face opportunities of cross-border trade and investment as well as threats of survival in a fastchanging environment with intensified competition, businesses operating in the global marketplace are increasingly concerned about efficiency, flexibility, and security in their international business activities. These circumstances seem to suggest an increase in importance of research on effects of regional economic integration on enterprise investment and business strategies.

This chapter first provides a broad overview of the development of regional economic integration in the world economy, including a brief understanding of the WTO, characteristics of regional economic integration, and the development of FTAs in the world as well as trade liberalization in Asia-Pacific. Section 2.3 considers the international competitiveness of firms at the micro-economic level to theoretically learn about the impact of trade liberalization on their international competitiveness. In section 2.4, a competitive strategy framework will be developed and interpreted on the basis of a review of literature in 
international strategic management. Section 2.5 discusses the New Zealand and Chinese economies in terms of international trade and investment, and reviews the nature of the New Zealand-China free trade relationship. Section 2.6 presents an in-depth analysis on the New Zealand natural health products industry under the New Zealand-China FTA. Lastly, the chapter will finish with a summary of the literature review with research questions.

\subsection{Regionalization in the World Economy}

\subsubsection{The World Trade Organization}

The World Trade Organization (WTO), the successor institution to the General Agreement on Tariffs and Trade (GATT) established in the wake of World War $\Pi$, has significantly reinforced multilateral control over international trade at a global or near-global level. As of August 2007, membership in the WTO has reached 151 countries, including a large majority of the world's major economies and trading nations. Today, the WTO represents over 95\% of world trade (Lee, 2006; WTO, 2007a).

Over the past half century, the WTO and GATT have helped to create a strong and prosperous multilateral trading system contributing to exceptional growth in the global economy. The system was developed through a series of trade negotiations or rounds between member countries. The bulk of the WTO's current work comes from the 1986-94 negotiations called the Uruguay Round and earlier negotiations under GATT. More recently, The WTO is the host to new negotiations, under the "Doha Development Agenda (DDA)", which was launched in Qatar in November 2001. The creation of DDA aims to reduce trade 
barriers and permit free trade between countries of varying prosperity through negotiations and further work on non-agricultural tariffs, trade and environment, WTO rules such as anti-dumping and subsidies, investment, competition policy, trade facilitation, transparency in government procurement, and intellectual property (WTO, 2007a).

However, the DDA suffered a major setback with the failure of the WTO Ministerial Conference in Cancun in September 2003, where efforts by members to agree to a broad negotiating framework broke down. The main stumbling block was the wide difference between developing and developed member countries across virtually all topics, typically agriculture and trade facilitation. For instance, the major developed member countries were not inclined to liberalize their agricultural sectors anywhere near as much as developing countries wished and the latter were reluctant to enter into negotiations on new issues of trade facilitation, especially investment and competition (Acharya \& Daly, 2004; Fergusson, 2008). By early 2008, talks stalled over a divide between the developed countries led by the European Union, the United States and Japan, and the major developing countries represented by the G20 developing nations such as China, India, Brazil, and South Africa (Wikipedia, 2007).

As a consequence, there has been an increasing discontent by certain members (particularly developing countries and countries that rely on agricultural products export, such as China and New Zealand), as they are frustrated with the sluggish progress of the WTO Rounds. The growing discontent has prompted many countries to look for regional alternatives. Therefore, it is not surprising that 
RTAs have become a very prominent feature of the multilateral trading system in the world. The WTO members are permitted to enter into RTAs under strict rules, due to the fact that RTAs can often support the WTO's multilateral trading system by allowing groups of countries to negotiate rules and commitments that go beyond what was possible at the time under the WTO (Villareal, 2005). As of July 2007, 380 RTAs have been notified to the GATT/WTO, 205 of which are currently in force (WTO, 2007b). By entering into RTAs, groups of countries are able to reduce trade barriers more rapidly than can be achieved under the WTO provisions. In particular, regionalization enhances the effectiveness of the WTO negotiations; helps reduce and manage the complexity of the WTO Rounds, and therefore restrains the risks of participation in the WTO (Zahrnt, 2005).

\subsubsection{Regional Economic Integration}

\subsubsection{Theory}

Regional economic integration has been a topical issue of considerable economic analysis beginning with Viner's original investigation of the customs union issue in 1950. Then, the major aspects of Viner's seminal analysis were endured and extended by economists in the 1960s (Derosa, 1998). The basic theory of regional economic integration was initially produced by Balassa (1961), which indicates that economic integration increases as national trade political boundaries reduce.

Nowadays, the term “regional economic integration” is likely to refer to a group of countries linking their economies together through agreements in reducing, and ultimately removing tariff and non-tariff barriers to the free flow of goods, 
services, and production factors between each other, with objective of achieving a higher level of economic performance that will benefit all the participating countries (Hill, 2005). Contrary to what the name suggests, these groupings or unions may be concluded between countries not necessarily belonging to the same geographical region (Tong \& Tong, 2007).

Depending upon the level of integration, regional economic integration exists in a multiplicity of forms, which generally consist of : (1) a free trade agreement (barriers to the trade of goods and services between two or more countries are removed, but each country determines its own external trade policy); (2) a customs union (a free trade agreement plus a common external trade policy); (3) a common market (a customs union plus free flow of labour, capital and other production factors between member countries); (4) an economic union (a common market plus the establishment of a common currency, the harmonization of tax rates, and a common monetary and fiscal policy); or (5) a political union (a central political apparatus coordinates the economic, social and foreign policy of the member countries) (Hill, 2005; Akoorie \& Scott-Kennel, 2005).

\subsubsection{Era of Regional Economic Integration}

The past few decades have witnessed an unprecedented proliferation of RTAs. WTO members are bound to notify the WTO of any RTAs in which they participate. By 2008, nearly all of the WTO's Members have notified participation in either bilateral or multilateral agreements (WTO, 2007b). Figure 2.1 considers the scale of the RTA phenomenon by listing the total number of 
RTAs (including inactive RTAs) notified over time to the GATT/WTO. As can be seen from the chart, the number of RTAs doubled between 1993 and 2000, but increased more than four-fold between 2000 and 2007. Meanwhile, a series of regional trading blocs have come into being by agreements such as the North American Free Trade Agreement (NAFTA) and by regional economic regimes such as the European Union (EU), which not only allow the participating countries to lower trade barriers among neighbours and political allies, but also retain flexibility over which sectors to liberalize and which issues to negotiate (GTN, 2004).

\section{Figure 2.1}

All RTAs notified to the GATT/WTO (1948-2007), by year of entry into force

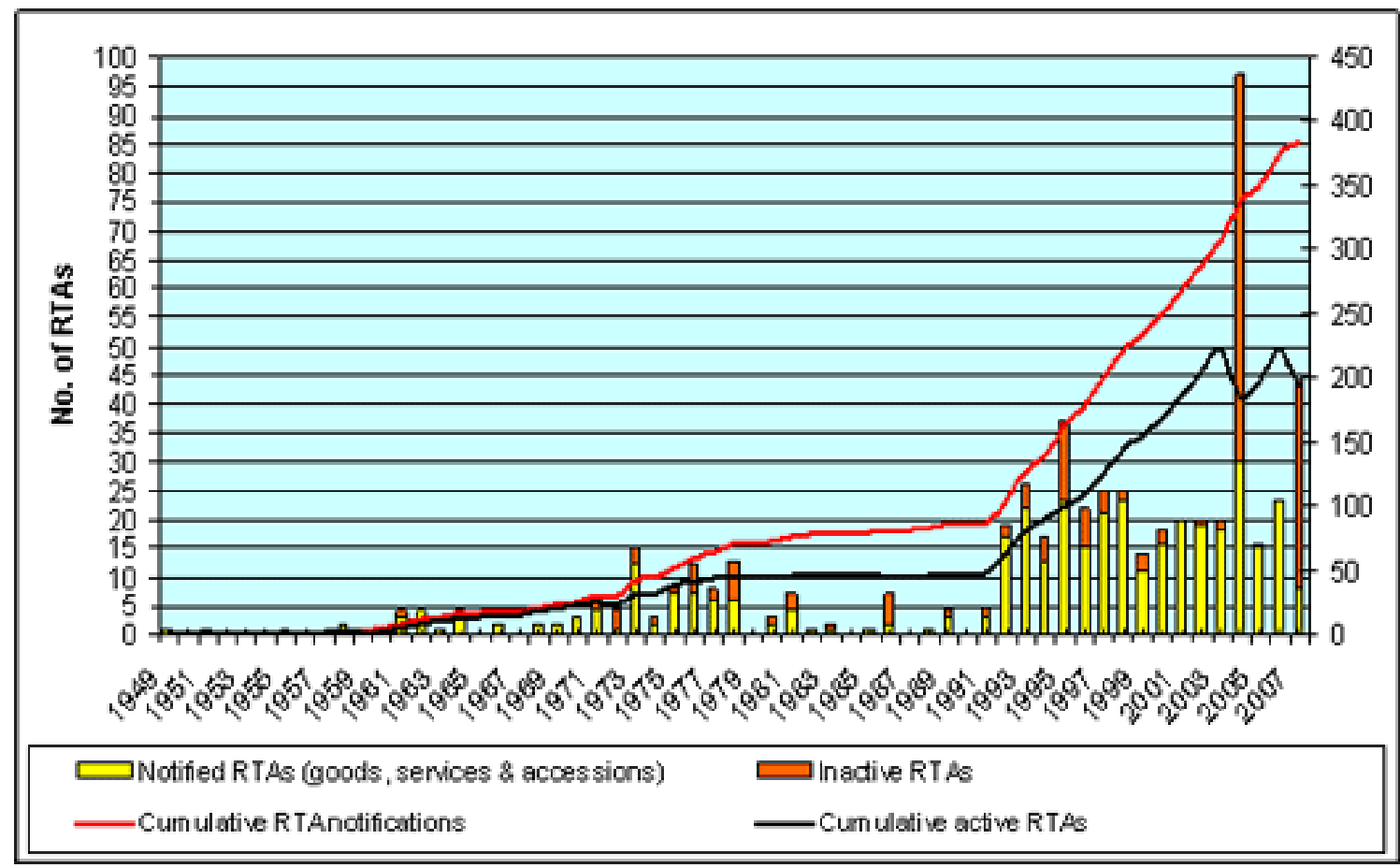

Source: WTO (2007b).

\subsubsection{Characteristics and Development of Free Trade Agreements}

The vast majority of regional trading arrangements are in the form of a FTA. As of December 2006, FTAs accounted for 84 per cent of all worldwide RTAs 
notified and in force. Of the projected RTAs, 92 per cent are intended to be FTAs (see Figure 2.2 and 2.3). The preference for FTAs seems to be a reflection of the defining characteristics of the current RTA race, which appear to be speed, flexibility and selectivity (Fiorentino et al., 2006). In most cases, the FTA is the best option to meet these needs. Comparing with other RTA forms, FTAs have faster and easier negotiating processes; give participating countries more flexibility in terms of the desired trade policy scope and choice of partners; and require lower degree of policy coordination amongst participating countries since each member country is allowed to determine its own policies with regard to non-members (Crawford \& Fiorentino, 2005).

Figure 2.2 Notified RTAs in force, as of December 2006, by type of agreement

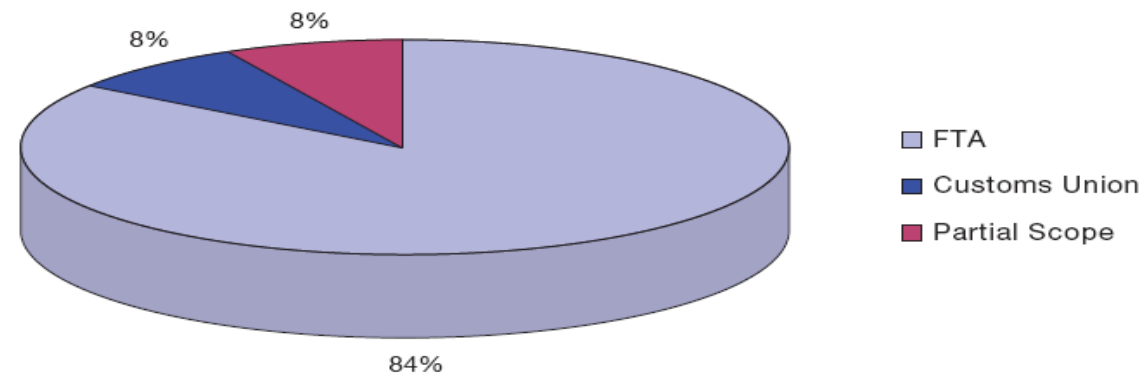

Source: Fiorentino et al., 2006

Figure 2.3

RTAs signed, under negotiation and proposed, as of December 2006, by type of agreement

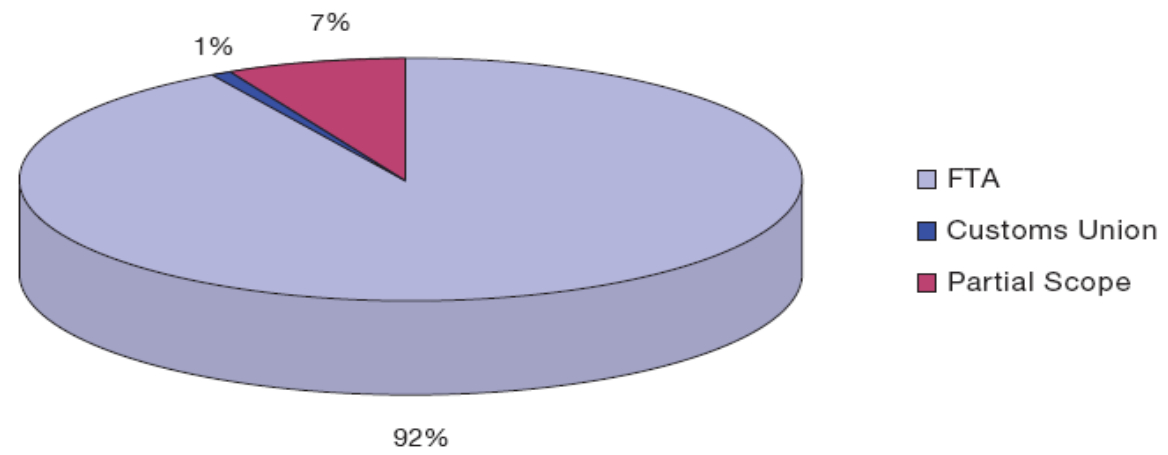

Source: Fiorentino et al., 2006 
With the rapid growth of FTAs, new characteristics are emerging. Countries are inclined to seek high-quality comprehensive FTAs, which not only traditionally cover trade in goods, services and investment, but also appear to have a set of supporting rules areas and aspects of relationship for closer consultation and cooperation. The Japan-Singapore FTA, for example, is a very deep agreement that includes liberalisation and facilitation of goods, services, and foreign investments, as well as common rules in a wide range of areas, involving of labour mobility, intellectual property rights, competition policies, and government procurements (Miyagawa et al., 2000).

\subsubsection{Trade Liberalization in Asia-Pacific}

Countries in the Asia-Pacific region have increasingly consolidated their drive towards regionalism. The process of trade and investment regional integration has developed significantly since early 1990s. Numerous attempts at trade liberalization and financial integration have been tried throughout the region (see Table 2.1). Perhaps the most well-known ones are the Association of Southeast Asian Nations (ASEAN) and the Asia-Pacific Economic Cooperation (APEC). Comparing to the European experience, these economic blocs have formed in the absence of a formal institutional framework that facilitates regional cooperation, and thereby they are mainly market-driven, rather than institution-driven. The participating countries are generally aiming to create linkages across borders in search for profitable opportunities through trade, foreign direct investment (FDI), and other arrangements in accordance with changes in comparative advantage and industrial upgrading in these economies (Zhang, 2003). 
Table 2.1 Major trade arrangements in Asia-Pacific

\begin{tabular}{|c|c|}
\hline $\begin{array}{l}\text { Regional trade agreements (year of } \\
\text { signing, year into force) }\end{array}$ & $\begin{array}{l}\text { Bilateral trade agreements (year of } \\
\text { signing, year into force) }\end{array}$ \\
\hline $\begin{array}{l}\text { AFTA (ASEAN Free Trade Area, } \\
\text { 1992, 1993) } \\
\text { SAPTA (SAARC Preferential Trade } \\
\text { Agreement, 1993, 1995) } \\
\text { PICTA (Pacific Island Countries Trade } \\
\text { Agreement, 2001, 2001) } \\
\text { TPSEPA (Trans-Pacific Strategic } \\
\text { Economic Partnership Agreement, } \\
\text { 2005, 2006) }\end{array}$ & $\begin{array}{l}\text { Australia - New Zealand }(1983,1983) \\
\text { India - Sri Lanka }(1998,2000) \\
\text { New Zealand - Singapore }(2000,2001) \\
\text { Japan - Singapore }(2002,2002) \\
\text { Australia - Singapore }(2003,2003) \\
\text { Singapore - United States }(2003,2004) \\
\text { Chile - Korea (2003, 2004) } \\
\text { China - Macao SAR }(2003,2004) \\
\text { China - Hong Kong SAR }(2003,2004) \\
\text { China - Thailand }(2004,2004) \\
\text { India - Thailand }(2004,2004) \\
\text { Australia - United States }(2004,2005) \\
\text { Japan - Mexico }(2004,2005) \\
\text { New Zealand - Thailand }(2005,2005) \\
\text { Pakistan - Sri Lanka }(2005,2005) \\
\text { India - Singapore }(2005,2005) \\
\text { Korea - Singapore }(2006,2006) \\
\text { Japan - Malaysia }(2006,2006) \\
\text { Singapore - Panama }(2006,2006) \\
\text { Chile - Japan }(2007,2007) \\
\text { Pakistan - Malaysia }(2008,2008) \\
\text { China - New Zealand }(2008,2008)\end{array}$ \\
\hline
\end{tabular}

Source: Adapted from Feridhanusetyawan, 2005

At the country level, countries represented by Japan, Korea, China, New Zealand and Australia appear to have jumped on the free trade agreement bandwagon in the region. Developments within these countries over the last few years suggest that their focus on FTAs with neighbouring countries has broadened to include cross-regional partners (Fiorentino et al., 2006). Perhaps the most significant one is the New Zealand-China FTA signed on 7th April 2008, which represents a noteworthy milestone in the economic integration between countries with such different economic systems, and at such different stages of development. As members of the WTO and the APEC, both China and New Zealand are committed to strengthen the world's multilateral system and promoting regional economic development. 


\subsection{International Strategic Management and Free Trade Agreements}

The recent rash of FTAs between countries not only influences the nature of the world economy at the macro-economic level, but also affects the behaviour of the operating companies at the micro-economic level. A unifying notion recognized by scholars and economists is that trade liberalization causes major changes in business environment as well as business practices (Czinkota \& Ronkainen, 1997; Etemad \& Wright, 1999). Along with the business environmental changes as a result of easing market restrictions across borders, firms increasingly seek high efficiency, flexibility, and security in their international business operations. Therefore, strategic decisions and adjustments to get over intensified global competition and to take advantage of reduced trade barriers are of the essence for their long-term development and growth (Julien et al., 1994). This awareness highlights the needs to comprehend the business environmental changes arising from increasing trade liberalization and to investigate firms' strategic responses to these changes. Even though some scholars have conducted research to do so, much of their work is conceptual or only focused on the macro-economic effects of scale economies and productivity gains (e.g. Daly \& Rao, 1986). Although these factors are clearly important, strategic management decisions by managers are the basic source of any adjustments to free trade (Rugman \& Verbeke, 1990).

Theories of strategic management suggest that business strategy is equated widely with crafting and maintaining a sound fit between a commercial venture and external environment (Valentin, 2001). As can be seen from the framework in Figure 2.4, firms obtain international competitiveness by implementing a 
variety of effective strategies that enable firms to exploit internal strengths and avoid internal weaknesses for taking advantage of business environmental opportunities and neutralize external threats (Barney, 1991). In the situation of Cell 1, for example, the firm faces several business environmental opportunities and has numerous internal strengths that encourage pursuit of these opportunities (Pearce \& Robinson, 2007).

Figure 2.4 SWOT Analysis

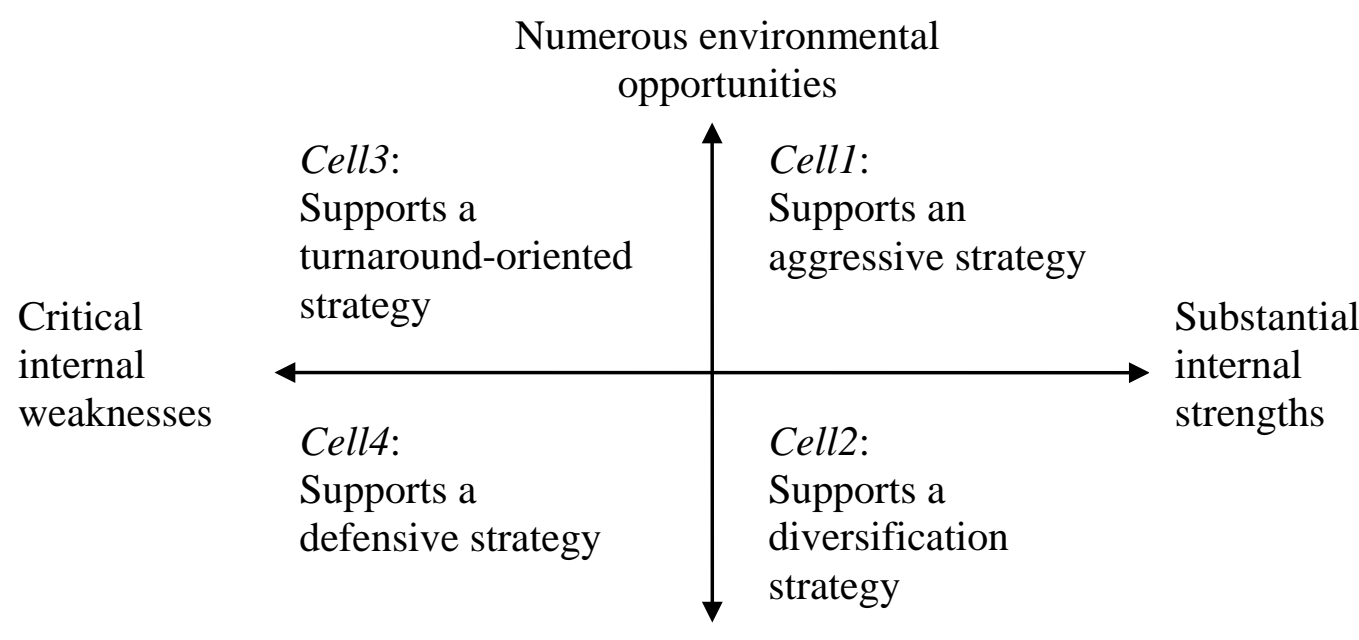

Major environmental threats

Source: Pearce \& Robinson, 2007, p155.

\subsubsection{Business Environment under the Free Trade Agreement}

\subsubsection{Opportunities}

From the viewpoint of an individual firm, an FTA can be seen as a two-edged sword. The removal of tariffs and other trade barriers between trading partners opens the markets that were formerly protected from foreign competition. In this context, trade liberalization provides firms with broader market access and hence customer base for their goods and services; allows them to specialize in the 
production of goods and services that they can produce most efficiently; and enables them to achieve greater economies of scale in production and in the wake of increased demand for products and services (Fisher et al., 2006).

Such opportunities are motivating firms to expand their foreign business activities by adopting strategic approaches such as the application of new technologies, the creation of new marketing and distribution channels, changes in organization and the like (Julien et al., 1994). In response to the changes created by EU after 1992, for example, 3M Company has been consolidating its European manufacturing and distribution facilities to take advantage of economies of scale after carefully considering the likely production costs in alternative locations with the EU (Hill, 2005).

\subsubsection{Threats}

Even after the elimination of barriers to trade and investment, however, enduring differences in cultures and competitive practices often limit abilities of firms to take advantage of freer trade. Cultural differences, for instance, often pose major difficulties in international negotiations and marketing management, which particularly reflect differences in personal values and in the assumptions people make about how business is operated (Hollensen, 2004). On the other hand, Fisher et al (2006) argue that the creation of a free trade area can pose substantially competitive challenges to firms in any given industries, and therefore exert greater pressures on firms to operate in both domestic and overseas markets. In this case, firms may either fear losing domestic market share to competitors that have benefited from economies of scale gained by 
international business activities, or fear losing potential opportunities in foreign markets permanently to domestic competitors that decide to focus on these markets, because market share is most easily retained by the firm that obtains it initially (Hollensen, 2004).

Such pressures generated by international competition will force firms to strive for their own survival by systematically improving their competitiveness which is generally considered to be developed through cross-national economies of scale, economies of scope, organizational learning, mergers, acquisitions, and the like (Roth, 1992). For example, there is no doubt whatever that Coca-Cola's move into overseas markets influenced Pepsi to move in the same direction, even though Coca-Cola internationalized much earlier than Pepsi did (Hollensen, 2004).

\subsubsection{Development of International Competitiveness}

With the potential opportunities and challenges brought by trade liberalization, firms may have a set of strategic goals in addition to the traditionally financial goals. They take steps to address the changing environmental conditions precipitated by transition to free trade as a mean of maintaining or enhancing their international competitiveness (Knight, 1997). At this point, free trade represents a fundamental change necessitating either proactive or reactive approaches. In other words, the prospect of easing market restrictions across boundaries causes firms to adopt either proactively or reactively strategic behaviour in response to the new business environment (Piercy, 1981; Gibson \& Harris, 1996). 
Proactive firms actively solicit more export sales, maintain regular contact with foreign customers, and put a higher priority on the business activities in the FTA member country markets (Campbell, 1996). These firms are generally stimulated to seek strategy change based on their interests in exploiting foreign market potential (Hollensen, 2004). In contrast, reactive firms are passive order-takers, for whom exporting is often less a priority than domestic sales. These firms usually react to pressures or threats from either their home markets or overseas markets, and consequently adjust passively by changing their operations over time (Campbell, 1996; Hollensen, 2004). A firm’s choice to adopt a proactive or reactive approach in response to free trade depends upon both perceived importance of free trade to the firm and on its resources and capabilities to expand internationally (Campell, 1996). Firms that feel affected significantly by free trade and are capable of mobilizing internal resources such as financial and managerial resources necessary to respond to overseas market opportunities are more likely to adopt a proactive approach to internationalize their business activities.

Firms that want to take advantages of free trade and assume global leadership in their industries must not only understand the economic environment (especially the potential environmental opportunities and threats), infrastructure development relative to other nations, and effects of membership in an FTA for various industries, but also understand valuable resources or capabilities the firm controls which enable it to exploit environmental opportunities or neutralize environmental threats. A clear understanding of these internal and external factors will subsequently lead to a deeper understanding for a firm to 
successfully formulate strategies in the market (Phatak et al., 2005; Barney, 2007).

\subsection{Conceptual Framework Development}

In general, the internal resources or capabilities and external business environmental factors from which a firm can benefit are conceptualized as firmspecific advantages (FSAs) and country-specific advantages (CSAs) respectively in the literature on strategic management (e.g. Rugman, 1986; Shan \& Hamilton, 1991; Rugman \& Verbeke, 1990). A strong firm-specific advantage or countyspecific advantage is defined here as an advantage sufficient to ensure competitiveness with respect to foreign rivals. The international competitive advantages which can be achieved by a firm depend upon both its FSAs and the CSAs facing the firm (Rugman \& Verbeke, 1990; Rugman \& Gestrin, 1993).

\subsubsection{Firm-Specific Advantages}

A resource-based perspective on strategic management in an international context suggests that a firm's potential competitiveness can be obtained by exploiting its strategic capabilities in terms of resources and competences, which are generally termed as FSAs (e.g. Fahy \& Smithee, 1999; Connor, 2002; Johnson et al., 2006). Any of a wide range of firm attributes (e.g. assets, capabilities, competencies, skills, know-how, and so forth) that enable the firm to conceive of and implement value-creating strategies designed to improve its efficiency and effectiveness in a country could be considered as its FSAs (Barney, 1991; 2007). These can be either production-based (cost or innovation 
advantages) or marketing-based (customization advantages) (Rugman \& Gestrin, 1993).

A number of scholars have created lists of firms' attributes that may enable them to formulate and implement strategies. These numerous possible resources are classified into four categories by Barney (2007), namely physical capital, financial capital, human capital, and organizational capital. Physical capital resources refer to the physical assets used in a firm such as its size, location, technical sophistication, access to raw material, and flexibility of plant and equipment. Financial capital resources include all the different money resources that can be used to implement strategies. For example, a firm's borrowing capability and its internal funds generation which determine its resilience and capability for investment. Human capital resources include training, experience, judgement, intelligence, relationships, and insight of individual managers and workers in a firm. Organizational capital resources include a firm's formal and informal planning, controlling, and coordinating systems; and its culture and reputation; as well as informal relations among groups within a firm and between a firm and those in its environment (Barney, 1991). These FSAs can be translated into cost or differentiation advantages through the effective formulation and implementation of competitive strategies (Rugman \& Verbeke, 1990).

Under free trade, trade and investment liberalization have an impact upon FSAs through its dynamic effects. Given a more open and competitive business environment, the FTA will force firms to develop strong FSAs, for example, 
through collaborating with local or international partners (Rugman \& Gestrin, 1993).

\subsubsection{Country-Specific Advantages}

The theory of international trade denotes that countries have various comparative advantages such as cheap and abundant labour, efficiency in the capital market, plentiful natural resources or advantaged technology infrastructure, due to differences in a range of macro-economic dimensions including economic, political, legal, and cultural (Hill, 2005). The international competitive advantage of companies in different industries may reflect the comparative advantages of nations embedded in them. The underlying comparative advantages of a nation may provide its firms with a competitive advantage at certain links of valueadded chains, such as, manufacturing, sales and marketing, or R\&D (Shan \& Hamilton, 1991).

Recent studies on the multinational operation and the international competitiveness of countries demonstrate that, in addition to FSAs, another important source of international competitive advantages is associated either with specific locations or the country of origin where the company possessing firmspecific resources and capabilities (e.g. Patel \& Vega, 1999; Porter, 2000; Jaffe \& Nebenzahl, 2001; Siddharthan \& Lakhera, 2005). These studies point out that the international competitiveness of firms is likely to depend on their ability to establish a presence in certain geographic locations to better access to consumers, employees, suppliers, specialized infrastructures, and the like (Bas \& Sierra, 2002; Li, 2004). For instance, foreign subsidiaries in different countries possess 
valuable connections with local cluster firms, government agencies, and research institutes, which allow them to be exposed to new ideas, knowledge and innovations of local systems (Yang \& Jiang, 2007).

In addition to gain competitive advantage from the comparative advantage of a host country, competitive advantage may also derived from a firm's home country advantages which is theoretically explained as the country of origin effect. Research on international marketing shows that consumers tend to generalize their perceptions across a wide range of products in a given country according to the national reputations in terms of product quality, technological superiority, innovation, or design (Patterson \& Tai, 1991). The country of origin effect is often being utilized by firms to differentiate and market their products. For example, Finnish multinational companies are successful in creating brands that have a strong Finnish flavour, conveying an image of Nordic life that is progressive, responsible and technologically advanced, as Finland draws upon its tradition of excellence in design as well as its long-standing policy of investing heavily in education and research (Ryan, 2008).

As FTAs' effects upon tariffs, rules of origin, and other trade and investment policies, trade liberalization has an immediate impact upon CSAs. The agreement may weaken an industry’s CSAs by removing protective measures to competitors in other member or non-member countries. In contrast, the agreement may strengthen an industry's CSAs with respect to competitors based in other member or non-member countries (Rugman \& Gestrin, 1993). Changes in CSAs arising from an FTA may lead to changes in a firm's particular operations, such 
as accessing to distribution channels and product differentiation. From this viewpoint, free trade requires firms to adjust their competitive strategy in order to benefit from CSAs (Rugman \& Verbeke, 1990).

\subsubsection{Competitive Strategy Framework}

Building on the nature of FSAs and CSAs, studies on international strategic management demonstrate that firms in the global business environment are able to pursue three strategic orientations: (1) cost leadership strategies where economies of scale, and lower costs are achieved through efficiency and global volume; (2) global differentiation strategies where seek to offer more value to the customers by tailoring products to local needs; and (3) focus strategies where concentrate on a distinct market segment defined by customer characteristics and /or geographic location. In a focus strategy, the firm still needs to decide whether to pursue cost leadership or product differentiation (Porter, 1985; Baird et al., 1994; Akoorie \& Scott-Kennel, 2005). By combining factors particular to the firm and the country with the three generic strategies described above, Rugman and Verbeke (1990) developed an analytical framework that allows us to conceptualize adjustment decisions in response to free trade. The theoretical model underpinning this study is adapted from this framework to assessing the competitive position of New Zealand's businesses and predicting their strategic adjustments to the New Zealand-China FTA (see Figure 2.5).

As can be seen from the matrix, international competitiveness can be achieved whenever FSAs and CSAs are strong simultaneously (quadrant 1). With their worldwide competitive advantage, firms are able to adopt any of the three 
generic strategies as described above. They may seek both cost efficiencies as well as revenue benefit of differentiation by taking advantage of FSAs and CSAs (Rugman \& Gestrin, 1993). For instance, firms may upgrade products to meet stricter product quality standards, offer training to produce a more qualified workforce, spur increased investment in R\&D and innovation, open new distribution channels, target narrow market segments, or make products more universally desirable (Julien et al., 1994; Campbell, 1996; Knight, 1997).

Figure 2.5 Competitive Strategy Matrix

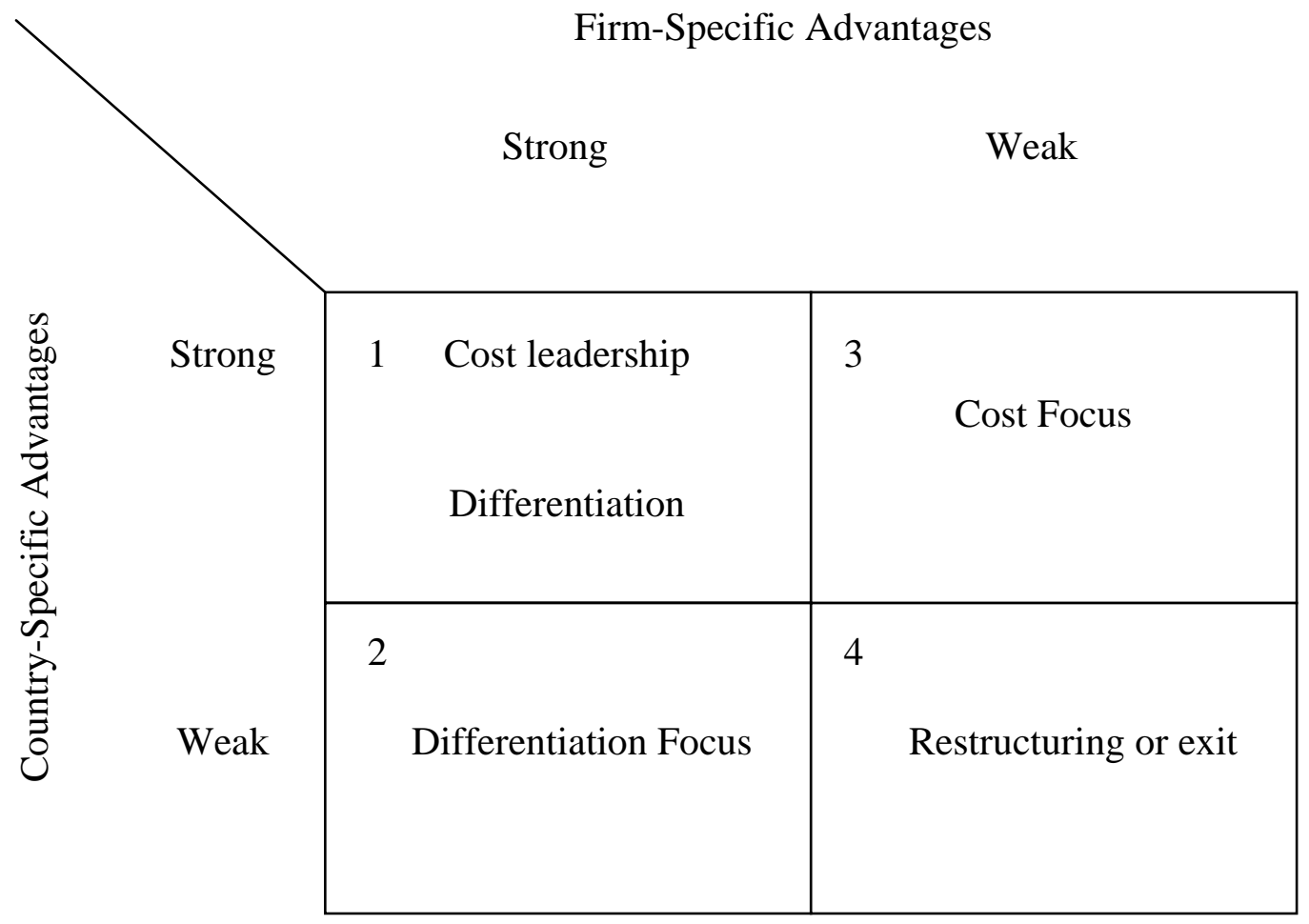

Source: Adapted from Rugman \& Verbeke, 1990, p256.

If CSAs are weak, however, strong FSAs will be essential for firms to compete with foreign rivals (quadrant 2). They usually confine themselves to some form of differentiation focus in order to beat their rivals benefiting from strong CSAs. With significant FSAs, firms are trying to achieve maximum local 
responsiveness, extensively customizing or differentiating products and marketing strategies to suit different national conditions (Akoorie \& ScottKennel, 2005). Due to weak CSAs, however, such operations can only be compensated by reducing their geographic or segment scope (Rugman \& Verbeke, 1990). In this situation, trade liberalization may generate strong regionspecific advantages (RSAs) such as cost reduction resulting from the removal of tariffs and other trade barriers, which can pay costs of weak CSAs.

A similar situation arises when strong CSAs have to compensate for the absence of strong FSAs in order to compete in the global market (quadrant 3). In this case, international competitiveness might be maintained by exploiting cost and location economies. Firms usually focus on operating in narrow but well-defined market segments and manufacturing a standardised product that can be marketed internationally (Akoorie \& Scott-Kennel, 2005). Furthermore, benefiting from strong CSAs or RSAs based on an FTA, firms can optimize the location of their activities. The location of activities in relation to each other as well as buyers and suppliers often contributes significantly to such things as labour rates, logistical efficiency, and supplier access, which would provide them with significant cost advantages (Porter, 1985).

Finally, firms lacking both FSAs and CSAs will be unable to compete internationally with respect to efficient foreign rivals. These firms are likely to restructure or exit (quadrant 4) (Rugman \& Verbeke, 1990). 


\subsection{The Bilateral Relationship Development between New Zealand and China}

\subsubsection{The New Zealand Economy}

The New Zealand economy is one of the most open and dynamic market economies in the world. As an isolated and small island with limited resources, the New Zealand economic well-being is largely dependent on high levels of exporting and foreign investment by local businesses (NZMFAT, 2004). According to Statistics New Zealand, the goods and services exports in New Zealand were valued US\$40 billion and US\$12.7 billion respectively in 2008, while the outward FDI was steady at around \$20 billion between 2004 and 2008 (STATSNZ, 2008). New Zealand can not make and sustain high rates of economic growth without international business activities, because exporting and investing abroad provide great scale, growth and learning opportunities for New Zealand's businesses (Skilling \& Boven, 2006).

Strong international connections and advanced access to global markets have always been fundamental to the New Zealand economic strategy over the past few decades (NZMFAT, 2004). New Zealand has pursued a mixed economy that operates on free market principles. It has committed to deepen economic integration with the rest of the world by continuously promoting involvement in multilateral, trilateral and bilateral trade arrangements, which largely assist New Zealand businesses into global markets (Akoorie \& Scott-Kennel, 2005). More recently, New Zealand's approach to improve its level of international trade and investment engagements places heavy emphasis on securing bilateral and regional FTAs, which has gradually supplemented the previous focus on multilateral trade liberalization through the WTO (Skilling \& Boven, 2006). 
New Zealand targets significant markets such as Australia, the US, China and Japan on a country-to-country basis, and seeks high-quality comprehensive FTAs with these countries which not only cover trade in goods, services and investment, but also supporting rules areas and aspects of the relationship for closer consultation and cooperation (NZMFAT, 2007). Table 2.2 illustrates New Zealand's merchandise trade with its top 10 trading partners. As is shown, Australia continued to be New Zealand's single largest export market, taking 22.9 percent of merchandise exports. The US and Japan are New Zealand's second and third largest export markets, accounting for 10 percent and 8.4 percent respectively. China is New Zealand's fourth largest export market with 5.2 percent of merchandise exports, but third largest trading partner with nearly NZ\$8 billion or 9.4 percent of total trade (STATSNZ, 2008).

Table 2.2 New Zealand Merchandise Trade with Major Trading Partners (Year ended June 2008)

\begin{tabular}{|c|c|c|c|c|c|c|c|c|}
\hline \multirow{2}{*}{ Rank } & Country & \multicolumn{2}{|c|}{ Exports } & \multicolumn{2}{c|}{ Imports } & \multicolumn{2}{c|}{ Total Trade } & $\begin{array}{c}\text { Trade } \\
\text { Balance }\end{array}$ \\
\cline { 3 - 9 } & & $\begin{array}{c}\text { NZ\$(bi } \\
\text { llion) }\end{array}$ & $\begin{array}{c}\text { \% of } \\
\text { total }\end{array}$ & $\begin{array}{c}\text { NZ\$(bill } \\
\text { ion) }\end{array}$ & $\begin{array}{c}\text { \% of } \\
\text { total }\end{array}$ & $\begin{array}{c}\text { NZ\$(billi } \\
\text { on) }\end{array}$ & $\begin{array}{c}\text { \% of } \\
\text { total }\end{array}$ & $\begin{array}{c}\text { NZ\$(bill } \\
\text { ion) }\end{array}$ \\
\hline $\mathbf{1}$ & Australia & 9.2 & 22.9 & 8.7 & 19.5 & 17.8 & 21.1 & 0.5 \\
\hline $\mathbf{2}$ & US & 4.0 & 10.0 & 4.1 & 9.3 & 8.1 & 9.6 & -0.1 \\
\hline $\mathbf{3}$ & China & 2.0 & 5.2 & 5.8 & 13.1 & 7.8 & 9.4 & -3.8 \\
\hline $\mathbf{4}$ & Japan & 3.3 & 8.4 & 4.0 & 9.1 & 7.3 & 8.8 & -0.7 \\
\hline $\mathbf{5}$ & Singapore & 0.9 & 2.2 & 2.2 & 5.1 & 3.1 & 3.7 & -1.3 \\
\hline $\mathbf{6}$ & Germany & 0.8 & 2.1 & 2.0 & 4.5 & 2.9 & 3.4 & -1.2 \\
\hline $\mathbf{7}$ & UK & 1.6 & 4.1 & 1.1 & 2.4 & 2.7 & 3.2 & 0.5 \\
\hline $\mathbf{8}$ & Malaysia & 0.9 & 2.1 & 1.8 & 4.1 & 2.7 & 3.2 & -0.9 \\
\hline $\mathbf{9}$ & Korea & 1.4 & 3.4 & 1.1 & 2.4 & 2.5 & 2.9 & 0.3 \\
\hline $\mathbf{1 0}$ & Thailand & 0.8 & 2.0 & 1.2 & 2.8 & 2.0 & 2.4 & -0.4 \\
\hline
\end{tabular}

Source: STATSNZ, 2008

In addition to trading partnerships, New Zealand is also committed to build Closer Economic Partnerships or Strategically Economic Partnerships with these countries through FTAs. The Australia-New Zealand Closer Economic Relations Agreement (CER), for example, has been described by the WTO “the world's 
most comprehensive, effective and mutually compatible free trade agreement” (NZMFAT, 2007).

Looking to the future, New Zealand continues to stimulate the long-term sustainable economic growth by substantially improving the level of its international economic engagement in global markets, most importantly, Australia, the US, and China.

\subsubsection{The Chinese Economy}

Since its adoption of the economic reform and open-door policy in 1979, China has become the world's fastest growing economy with an average annual real GDP growth rate of 9.7 percent from 1979 to 2005. Real GDP grew beyond 10 percent every year since 2006 (Morrison, 2007). This “Chinese miracle” was largely achieved through the China's gradual market-oriented transition and increasing integration into the global economy.

Trade and foreign investment are increasingly playing remarkable roles in China’s thriving economy. From 1979 to 2006, China’s exports rose from US\$14 billion to US\$ 969 billion, while imports grew from US\$16 billion to US\$792 billion (see Table 2.3). After its access to the WTO in December 2001, China's active movement in international trade through either bilateral or multilateral FTAs makes it become the third largest trading economy in the world, just behind the US and Germany. With an average growing rate of nearly 30 percent in total foreign trade (total exports and imports based on current trade), China is expected to account for around half of the world trade by 2010 (Whalley, 2006). 
Table 2.3 China's Merchandise Trade, 1979-2006 (US\$ billion)

\begin{tabular}{|c|c|c|c|c|}
\hline Year & Exports & Imports & $\begin{array}{c}\text { Total } \\
\text { Exports \& } \\
\text { Imports }\end{array}$ & Balance \\
\hline $\mathbf{1 9 7 9}$ & 13.7 & 15.7 & 29.4 & -2 \\
\hline $\mathbf{1 9 8 0}$ & 18.1 & 19.5 & 28.6 & -1.4 \\
\hline $\mathbf{1 9 8 5}$ & 27.3 & 42.5 & 69.8 & -15.3 \\
\hline $\mathbf{1 9 9 0}$ & 62.9 & 53.9 & 116.8 & 9.0 \\
\hline $\mathbf{1 9 9 5}$ & 148.8 & 132.1 & 280.9 & 16.7 \\
\hline $\mathbf{2 0 0 0}$ & 249.2 & 225.1 & 474.3 & 24.1 \\
\hline $\mathbf{2 0 0 1}$ & 266.2 & 243.6 & 509.8 & 22.6 \\
\hline $\mathbf{2 0 0 2}$ & 325.6 & 295.2 & 620.8 & 30.4 \\
\hline $\mathbf{2 0 0 3}$ & 438.4 & 412.8 & 851.2 & 25.6 \\
\hline $\mathbf{2 0 0 4}$ & 593.4 & 561.4 & 1154.8 & 32 \\
\hline $\mathbf{2 0 0 5}$ & 762.0 & 660.1 & 1422.1 & 101.9 \\
\hline $\mathbf{2 0 0 6}$ & 969.1 & 791.5 & 1760.6 & 177.6 \\
\hline
\end{tabular}

Source: Morrison, 2007 and China Statistics Yearbook, 2007.

On the other hand, inward FDI for the so-called manufacturing platform has been a central element in fuelling export growth in China. While thousands of multinational enterprises (MNEs) have extensive manufacturing operations in China in order to sell their products in the booming Chinese market and to take advantage of low-cost manufacturing base, over half of China's trade is conducted by these firms operating in China(Morrison, 2007).

During 30 years of economic reform and openness, China has become one of the most attractive destinations in the globe for cross-border direct investment. As a result of the active government promotion of FDI inflow through a series of policies, FDI in China has grown rapidly since late 1990s. According to China Statistics, the contracted FDI inflow to China has grown from about US\$62.4 billion in 2000 to more than US\$200 billion in 2006, while the China's actual utilization of FDI grew from US\$40 billion to nearly US\$70 billion during the same period (see Table 2.4). Today, China has become world's largest FDI 
receiver among developing countries. And it accounts for around 60 percent of total FDI flows from OECD to non-OECD countries (Fung et al., 2002; Whalley, 2006).

Table 2.4 Contracted and Actual FDI in China, 1979-2006 (US\$ billion)

\begin{tabular}{|c|c|c|}
\hline Year & Contracted FDI & Actual FDI \\
\hline $\mathbf{1 9 7 9 - 1 9 8 4}$ & 9.7 & 2.1 \\
\hline $\mathbf{1 9 8 5}$ & 6.3 & 3.5 \\
\hline $\mathbf{1 9 9 0}$ & 5.6 & 37.5 \\
\hline $\mathbf{1 9 9 5}$ & 91.2 & 40.7 \\
\hline $\mathbf{2 0 0 0}$ & 62.4 & 46.9 \\
\hline $\mathbf{2 0 0 1}$ & 69.2 & 52.7 \\
\hline $\mathbf{2 0 0 2}$ & 82.8 & 53.5 \\
\hline $\mathbf{2 0 0 3}$ & 115.1 & 60.6 \\
\hline $\mathbf{2 0 0 4}$ & 153.5 & 60.3 \\
\hline $\mathbf{2 0 0 5}$ & 189.1 & 69.5 \\
\hline $\mathbf{2 0 0 6}$ & 200.2 & \\
\hline
\end{tabular}

Source: China Statistics Yearbook, 2007.

Looking to the future, a huge population with high growth rate of the middle class, and rapid-growing economy continuously make China the most attractive to international companies as a target market, a manufacturing platform, and a sourcing destination (Cavusgil et al., 2008).

\subsubsection{Bilateral Economic and Trade Relations between New Zealand and China}

From the above statements of two economies, New Zealand and China have enjoyed considerable economic success over the past decade. As open and dynamic economies in the world, continuously strengthening international 
linkages and improving access to overseas markets are reflected in both countries’ long-term economic development strategies.

The trade and economic relationships between two countries have grown significantly in recent years, largely reflecting comparative economic strengths, economic complementarities and a strengthening investment correlation (See Table 2.5). As a significant player in the WTO and APEC, New Zealand's third largest trading partner, and a major source of migrants, tourists, students and foreign investments, China is increasingly important to New Zealand's economy as a bilateral, regional and multilateral partner. In contrast, as an active member in the OECD, the WTO and APEC, it is one of China's most important trading partners in agricultural and forestry products, China also attaches great importance to develop close cooperative ties with New Zealand, particularly in trade, investment, technology, agriculture, education and tourism (NZMFAT, 2004).

Building on a long history in working together to strengthen the multilateral trade system and to promote the regional economic development in the WTO and APEC contexts, New Zealand and China have been committed to build up longstanding and healthy bilateral trade and economic partnerships. An FTA was signed on $7^{\text {th }}$ of April 2008 following a fifteen rounds negotiation process over three years, and entered into force on $1^{\text {st }}$ of October 2008 (NZMFAT, 2009). The FTA is seen as a high quality arrangement that is expected to liberalize and facilitate the trade in goods, services and investment between two countries. It also contains measures to improve the business environment and promote 
Table 2.5 The Complementary Relationship between New Zealand and China (2007)

\begin{tabular}{|c|c|c|}
\hline & New Zealand & China \\
\hline $\begin{array}{l}\text { Merchandise } \\
\text { Trade }\end{array}$ & $\begin{array}{l}\text { - China is New Zealand’s fourth } \\
\text { largest overseas market. } \\
\text { New Zealand's exports to China } \\
\text { were worth around US\$1.5 } \\
\text { billion. } \\
\text { - New Zealand's exports to China } \\
\text { are dominated by agricultural } \\
\text { products, mainly, dairy, wool, } \\
\text { oils and fats, accompanied by } \\
\text { non-agricultural products such as } \\
\text { forestry, seafood, machinery, } \\
\text { aluminium, and high-tech } \\
\text { products }\end{array}$ & $\begin{array}{l}\text { - } \quad \text { New Zealand is China's } 57^{\text {th }} \\
\text { largest overseas market. } \\
\text { China's exports to New Zealand } \\
\text { were worth around US } \$ 1.8 \\
\text { billion } \\
\text { - China's exports to New Zealand } \\
\text { mainly include electrical } \\
\text { machinery and equipment, } \\
\text { textiles, clothing and footwear, } \\
\text { toys, and a wide range of light } \\
\text { consumer goods. }\end{array}$ \\
\hline $\begin{array}{l}\text { Trade in } \\
\text { Services }\end{array}$ & $\begin{array}{l}\text { - Education and tourism are New } \\
\text { Zealand's major services exports } \\
\text { to China. } \\
\text { China is the fifth largest source of } \\
\text { visitors. More than 120, 000 } \\
\text { Chinese tourists visited New } \\
\text { Zealand. They made an economic } \\
\text { contribution in nearly US\$200 } \\
\text { million. } \\
\text { China remains New Zealand's } \\
\text { most significant source of foreign } \\
\text { students. Around 28, 879 Chinese } \\
\text { students studied in New Zealand, } \\
\text { which account for about 32\% of } \\
\text { New Zealand's total foreign } \\
\text { students. }\end{array}$ & $\begin{array}{l}\text { - New Zealand is the } 21^{\text {st }} \text { largest } \\
\text { source of visitors. More than } \\
\text { 89,000 New Zealand tourists } \\
\text { visited China. }\end{array}$ \\
\hline Investment & $\begin{array}{l}\text { China's investments in New } \\
\text { Zealand total in the vicinity of } \\
\text { US\$ } 84 \text { million in } 2006 \text {. } \\
\text { Most investment has been in the } \\
\text { forestry sector. There is also } \\
\text { significant investment in } \\
\text { manufacturing and commercial } \\
\text { construction. Sectors such as } \\
\text { property, hotels and restaurants, } \\
\text { meat processing, electronics, fish } \\
\text { farming and tanning have all } \\
\text { attracted the interest of smaller } \\
\text { Chinese investors. }\end{array}$ & $\begin{array}{l}\text { - New Zealand companies such as } \\
\text { ANZ, Fonterra, Richina Pacific, } \\
\text { NDA Engineering, Hayes } \\
\text { International and PAN PAC have } \\
\text { major holdings in China. } \\
\text { There are a number of other } \\
\text { companies from or closely } \\
\text { associated with New Zealand with } \\
\text { strategic operations or } \\
\text { investments in China (e.g., Beca } \\
\text { Carter, Biovittoria, TL Jones } \\
\text { Microscan, University of Waikato } \\
\text { in Shanghai/East China, Air New } \\
\text { Zealand Engineering, Beca Carter, } \\
\text { Intuto, Natural History New } \\
\text { Zealand, Western Institute of } \\
\text { Technology Taranaki, Wools of } \\
\text { New Zealand in Beijing/North } \\
\text { China). } \\
\text { These companies see investment } \\
\text { in China as important to secure a } \\
\text { long-term market for New } \\
\text { Zealand products and to assist in } \\
\text { the penetration of the enormous } \\
\text { consumer market developing in } \\
\text { China. }\end{array}$ \\
\hline
\end{tabular}

Source: China Statistics, NZ Statistics, NZ Immigration, NZ Ministry of Tourism and NZ Ministry of Foreign Affairs \& Trade. 
cooperation in a broad range of economic areas of two countries' mutual interests such as banking and legislation (NZMFAT, 2008a). In particular, "the agreement will push forward bilateral comprehensive ties of cooperation to a higher level, open up new opportunities in trade and investment, and help both countries to develop a more open, stable and competitive business environment” said Wang Xinpei, the former spokesman of the Ministry of Commerce in China ( Xinhua, 2008a).

The FTA is extremely significant for New Zealand's economy. "It is New Zealand's largest bilateral trade agreement since the Closer Economic Relations (CER) agreement was signed with Australia in 1983. It will open up new economic opportunities for New Zealand's businesses to access to the world's fastest growing economy and boost their existing commercial links, and create new investment possibilities in China, especially since New Zealand is the first developed economy to conclude a comprehensive FTA with China” said New Zealand’s former Prime Minister, Helen Clark (Xinhua, 2008b).

Under the agreement, New Zealand's exporters will see a substantial saving in the cost of trading with China along with the phased elimination of tariffs that they face. According to New Zealand's former trade minister Phil Goff (2008), tariffs are removed on 96 percent of New Zealand's exports to China. Tariffs on more than NZ\$200 million worth of New Zealand's exports would be eliminated since the day that the FTA comes into force. As a result, New Zealand's exports to China are estimated to grow by US\$ $180-280$ million per year over the next twenty years between 2007 and 2027 (NZMFAT, 2004). Figure 2.6 shows the 
estimated reduction in duty payment on New Zealand's current exports to China over the implementation period of the FTA. Increased exports in response to tariff liberalization will create additional duty savings on a cumulative basis (NZMFAT, 2007).

\section{Figure 2.6: Reducing Duties on Total NZ Exports to China}

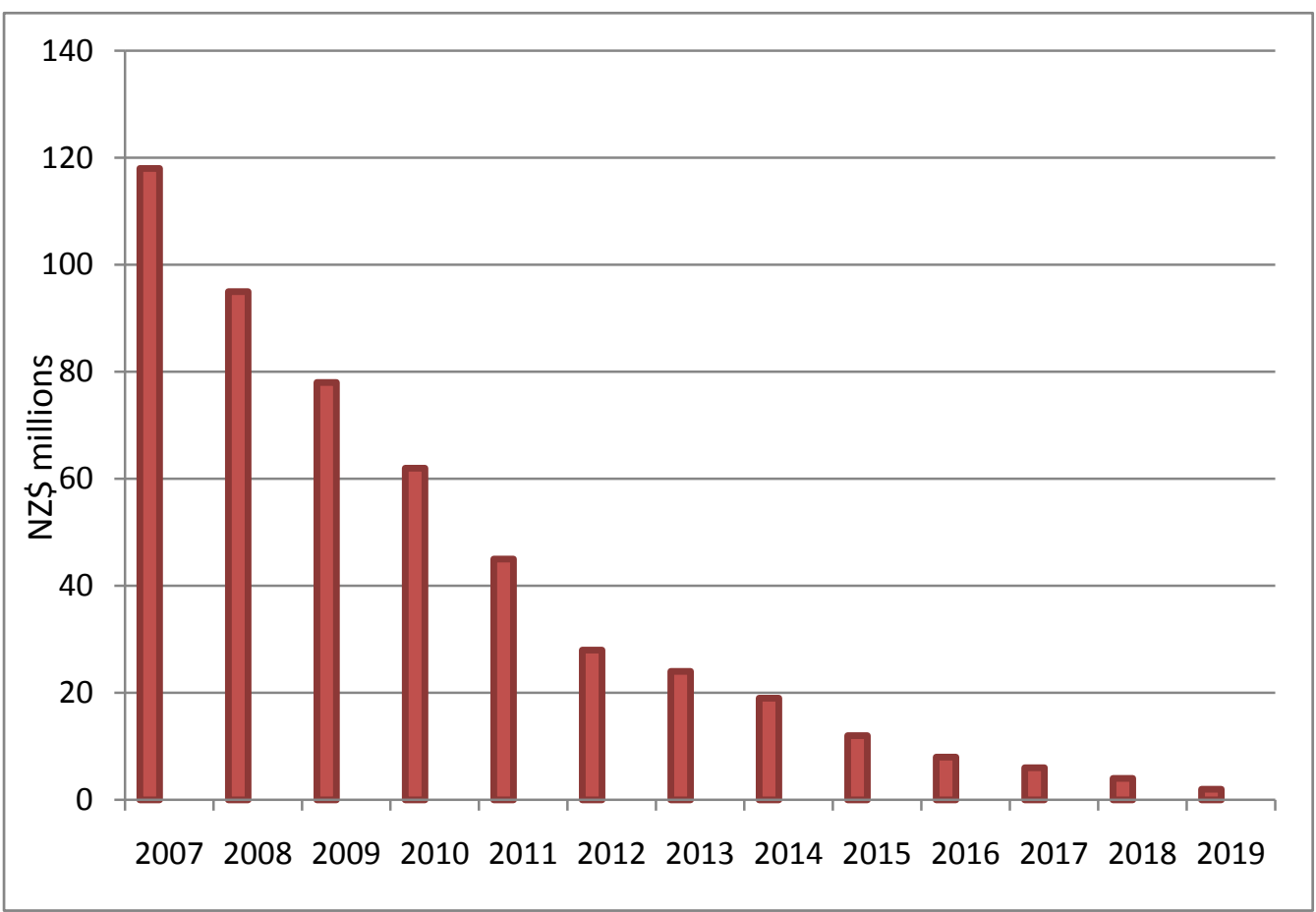

Source: NZMFAT, 2007.

In addition, the FTA also covers trade in services, facilitation of investment, and movement of people. Under the agreement, New Zealand's service providers will benefit from China's increased commitments in services such as education, tourism, and business consultancy. Besides, the FTA provides the New Zealand investors better protection for their investments in China, as well as a provision to ensure that they remain competitive with investors from other countries. In the area of human resources, New Zealand will also benefit from provisions that facilitate the travel of business people to China and from access to skilled 
workers from China in certain occupations where long-term skills shortages exist. In addition to economic cooperation, the agreement will also lead to greater collaboration in the areas of cultural societies, customs, government procurement, intellectual property, sanitary and phytosanitary ${ }^{1}$ measures (NZMFAT, 2008a).

\subsection{Impact of New Zealand-China FTA on New Zealand Natural Health Products Industry}

\subsubsection{The Background of the New Zealand Natural Health Products Industry}

With a pristine environment and unique biodiversity, New Zealand has a long track record of identifying and exploiting the medicinal and nutritional uses of natural products. From harnessing the antibacterial and healing properties of Manuka honey, to research and development on identifying a natural noncalorific food sweetener, New Zealand now has built a profitable and growing natural health products sector. The sector prides itself on a broad range of nutritional and functional foods activities (e.g. manufacturing, marketing and distributing on a world scale) and excels in areas such as natural cosmetics, health ingredients and natural pesticides (NZBIO, 2008). Combined with world leading edge scientific research, biotechnological knowledge and innovative tradition, New Zealand enjoys a world-class reputation as a major source of quality natural health products ${ }^{2}$.

\footnotetext{
${ }^{1}$ The inspection intended to prevent the spread and the introduction across national boundaries of pests of plants and plant products. (http://www.mijnwoordenboek.nl/definition/phytosanitary)

2 The natural health product definition in this study basically has two components: function and substance. The function component refers to the natural health product definition capturing those substances that are manufactured for use in diagnosis, treatment, mitigation or prevention of diseases in humans; restoring or correcting organic functions in humans; or modifying organic
} 
Although New Zealanders with higher levels of education and greater personal wealth are increasingly looking for positive health and lifestyle outcomes through the application of nutritional supplements and complementary healthcare products, New Zealand's small domestic market largely limits the development of its natural health products industry. Fortunately, a growing international demand for functional and nutritional foods is fuelling the rise of the natural health products industry in New Zealand. Benefiting from the development in the diverse and technology-based innovations which are driven by a wealth of research activities in several international-recognized research institutes and universities in New Zealand, a growing number of New Zealand's natural health product companies are successfully utilizing their managerial know-how in manufacturing, branding, marketing and distribution, biotechnological technology and unique materials in New Zealand to create competitive international businesses with a strong focus on new product development (NZTE, 2006a; 2006b).

According to Natural Products New Zealand, more than 70 percent of New Zealand's total export earnings are derived from biology-based industries ranging from primary industries (e.g., agriculture and horticulture) to newgeneration technologies (e.g., natural cosmetics, bioactive ingredients and nutraceuticals). It is conservatively estimated that New Zealand's natural health

functions in humans, such as modifying those functions in manner that maintains or promotes health. The substance refers to product available in a dosage form and can be comprised of natural resources or ingredients such as herbs, non-human animal materials or their extracts, vitamins or minerals.

(http://www.agwest.sk.ca/nutrition/documents/CanadianNaturalHealthProductsIndustry.doc) 
products exports contribute around NZ\$500 million annually to New Zealand economy, and have the potential for ongoing growth (NPNZ, n.d.).

In overseas markets, New Zealand's natural health product businesses have strongly engaged in Asia and North America, and have a growing presence in Europe. As a result of slowing economic growth in the US and Europe in recent years, New Zealand's firms are taking a close look at the fast growing, innovation and emerging markets for natural health products. Today, Asia has become the largest market for New Zealand's natural health products, especially health ingredients and functional foods, accounting for 56 percent of total export earnings from the sales of health ingredients ${ }^{3}$ and 64 percent of functional foods sales $^{4}$. The key export destinations are China, Hong Kong, Taiwan, Japan, Korea, Malaysia, Singapore and Vietnam (NZTE, 2006a).

\subsubsection{Trends and Potentials in the Chinese Natural Health Products Market}

Among Asian markets, China is the fastest growing market with huge potential for natural health products. Apart from the rapid economic growth and a close trade relationship with New Zealand, there are several reasons why China is expected to be a largest market for New Zealand's natural health products in the future.

\footnotetext{
${ }^{3}$ The total export sales of health ingredients are conservatively estimated at NZ\$31million annually (NZTE, 2006a).

${ }^{4}$ The total export sales of functional foods are conservatively estimated at NZ\$143million annually (NZTE, 2006a).
} 
The demand for most of the mass consumer goods is often triggered by the presence of an affluent middle class. The increased Chinese middle class driven by its continued strong economic growth is extremely important for both domestic and international businesses because they count on the huge consumer market with its significant purchasing power. In essence, the middle class in China is defined as the households with an annual income ranging from 60,000 yuan (US\$8,773) to 500,000 yuan (US\$73,105) (Xin, 2004). According to the research by Euromonitor International, China’s middle-class population has reached 80 million in 2007 (compared with 65.5 million in 2005). It is likely to grow to 100 million by 2010, and 700 million by 2020 (Hodgson, 2007). The fast-growing population of China's middle class and their rise in income will create strong purchasing power and remarkable demand for goods and services, and therefore provide great opportunities for businesses in a broad range of sectors such as banking, housing, food, healthcare, education and tourism.

On the other hand, people categorized in China's emerging middle class are usually living in urban areas, who are characterized by relatively younger ages (compared with those in most developed countries), higher levels of education, greater personal wealth and modern lifestyles. With the introduction of Western values, they are increasingly pursuing positive and healthy ways of living. And thereby they have a very high level of health consciousness, and greater concern over problems such as life-style diseases prevention, maintaining vigour, skin care, and dieting and obesity prevention in their daily life. They are willing and able to pay more for natural health products such as nutraceuticals, functional foods, energy drinks, slimming products and natural cosmetics (Briar, 2004). 
A McKinsey survey indicates that the private health expenditure by China's middle class is expected to rise more than 11 percent annually over the next two decades (Farrell et al., 2006). This growth in spending will generate huge demand ${ }^{5}$ for New Zealand's natural health products, because New Zealand's products have very high consumer acceptability in the Chinese market. With the preference of foreign health products over domestic, Chinese consumers are ready to pay extra for natural health products that are manufactured and packed in New Zealand (Briar, 2004).

\subsubsection{SWOT analysis on New Zealand Natural Health Products Industry under New Zealand-China FTA}

After an overview of the New Zealand natural health products industry and the Chinese natural health products market, it is essential to evaluate the New Zealand natural health products sector's strengths and weaknesses in relation to business environmental opportunities and threats arising from the New ZealandChina FTA (See Appendix A), because environmental opportunities are only potential opportunities unless the company is able to utilize its resources to take advantage of them.

\subsubsection{Strengths}

Traditionally, the key strengths of New Zealand's natural health products sector have been the abundant natural resources and international quality reputation for natural products. Due to its isolated geographic location, New Zealand enjoys ideal climatic and environmental conditions that provide fertile resources for

\footnotetext{
${ }^{5}$ It is estimated that natural health products will be able to generate a total revenue of 120 billion yuan (24 billion NZ dollars) by the end of 2010. ( Data sourced from People's Daily, Health and Food China, and San-Jiu National Health Forum 2003)
} 
producing a variety of biology-based products. Besides, New Zealand has more than 150 years experience in genetically improving animals and plants, which helps to create one of the world's most efficient agricultural economies (NZTE, 2005). Combined with a clean green image as projected by Tourism New Zealand, New Zealand is recognized internationally as a country with a track record of strict processing and food exporting regulations and the best animal health status in the world (NPNZ, n.d.). As a result, consumers around the world can be assured that natural health products originating in New Zealand are safe and uncontaminated.

In recent years, however, the New Zealand's natural health products sector has a growing emphasis on new and innovative ways to add value to primary products in order to better meet world-changing demand. The world-leading research by a large number of international-recognized research organizations and universities has provided specialist scientific expertise to assist firms in producing unique natural health products with proven global appeal. Moreover, the abundance of highly-trained technicians with excellent product development skills and strong support from government agencies such as New Zealand Trade and Enterprise and Natural Products New Zealand have ensured that New Zealand has knowledge-based competitive advantages in manufacturing, marketing, branding and distribution in the natural health products sector. For instance, New Zealand firms are able to produce high-quality value-added natural health products at much lower costs than their international competitors. These firms also have many years' experience in trading with Asian countries and close relationships 
developed in this region, which are fuelling the natural health products industry in New Zealand (NZTE, 2006a).

\subsubsection{Weaknesses}

The majority of New Zealand's natural health products companies are small to medium-sized. Compared with larger players, the major internal constraints for these companies to operate in a free trade environment are limited financial resources, and lack of market knowledge and experience. A recent survey by Natural Products New Zealand indicates that more than one third of firms in the sector consider finance and cost-related factors as their major barriers to expanding internationally. The lowering of trade barriers as a result of the New Zealand-China FTA presents smaller companies with great opportunities to penetrate into the Chinese market. However, New Zealand's natural health products companies have lower levels of productivity and fewer resources to capitalize on the increased export opportunities arising from free trade (Campbell, 1996). They are faced with exceptionally high costs that relate to regulatory compliance, marketing, branding and distribution in China's more complicated business environment (Briar, 2004). Inadequate information on potential customers, competition and business practices in China may increase hidden costs relating to language and cultural issues, and time spent building social relationships, distribution networks and intellectual property protection.

\subsubsection{Opportunities}

From an evaluation of the Chinese market above, the increasing demand for natural health products and the fast-growing purchasing power of the Chinese 
middle class offer enormous opportunities for New Zealand natural health products companies to expand in the Chinese market. Apart from increased export opportunities, the New Zealand-China FTA will also further enhance bilateral investment opportunities in the natural health products sectors in two countries. New Zealand and China have their own comparative advantages in this sector. For example, China has cheaper and large labour and manufacturing infrastructure resources; New Zealand has plentifully natural resources, and world-leading techniques in biotechnology research and application. Bilateral investment in the free trade environment would take advantage of vertical integration brought by complementary comparative advantages of the natural health products sectors in two countries. Correspondingly, the lower production costs and the prices of the final manufactured natural health products would be beneficial for producers and consumers in both countries (NZMFAT, 2004).

\subsubsection{Threats}

As mentioned earlier, the New Zealand-China FTA can also pose substantial competitive challenges to New Zealand's natural health products companies, and thereby exert greater pressures on them to operate in both the domestic market and the Chinese market. Some of them may either fear losing domestic market share to existing or new competitors that are able to benefit from economies of scale gained by their international business activities, or fear losing exporting and investment opportunities arising from the FTA (Hollensen, 2004).

On the other hand, the regulatory system in relation to foods, beverages, supplements and ingredients (FBSI) is extremely complex in China. Food safety, 
in particular, is a substantial concern. Recent food scares, for example, infant milk powder melamine contamination in China in February 2008, are likely to further stress trade between China and the West as well as erode domestic consumer confidence. With increased costs in regulatory requirements such as product licensing, this would create challenges for New Zealand's natural health products companies to export or establish a physical presence in the Chinese market (Tallon, 2008).

\subsection{Summary \& Research Questions}

From the analysis at the international, national and industrial levels above, New Zealand's natural health products companies with limited resources and capabilities are unlikely to be competitive in the Chinese market though they might benefit from certain national or industrial strengths and from an advantage of accessing the Chinese market as a result of the New Zealand-China FTA. Therefore, it would be interesting and worthy to conduct research on how successful companies in the New Zealand natural health products industry strategically respond to the New Zealand-China FTA. Building on the underlying rationale of the study which relates to strategic responses to trade liberalization, this research is guided by the following research questions:

1. How are New Zealand's firms seeking to take advantage of the opportunities arising from freer trade and neutralize threats created from the fast-changing business environment?

2. How do they maximize the strategic benefits by combination of their own firm-specific advantages and country-specific advantages facing them? 
3. And correspondingly, how do they translate these strategic benefits into sustainable competitive advantages that ensure their competitiveness with respect to foreign rivals?

By answering these three main questions, the paper is intended to present an understanding and recommendations concerning the ways in which New Zealand's businesses attempt to improve or dramatically change their competitive position in the global marketplace, especially in the Chinese market under the New Zealand-China FTA. 


\section{CHAPTER THREE: RESEARCH}

\section{METHODOLOGY}

\subsection{Introduction}

This chapter discusses the research methods used to assess the theories and investigate the research questions presented in the preceding chapter. This includes the approach and strategy used to undertake the research, the data collection process, the data analysis approach, and the explanation of the sample.

\subsection{Research Approach}

The basic aim of this research project is to gain a comprehensive understanding of strategic management decisions made by New Zealand's international companies in adjusting to the New Zealand-China FTA. To reach this purpose, a qualitative research approach has been chosen for conducting this research. According to Cavana, Delahaye and Sekaran (2001), qualitative research is interested in the subjective perception of the respondent, which is in examining the perspective of the respondent's beliefs and the interpretation of the phenomena being researched. The descriptions and theories created by this type of research are rooted in reality, which means the data material has its roots in the social existence conditions. Therefore, the qualitative research approach would be perfect to get more in-depth information that is needed to fulfil the research task, and to give an opportunity for practical insights rather than a statistical or theoretical analysis (Ersson \& Tryggvason, 2007). 


\subsection{Research Strategy}

Since this research places emphasis on creating understanding, explaining reasons, predicting results and suggesting measures through closely examining contemporary events, and focus on a qualitative study, the case study-based research method is ideal for a rich understanding of the dynamics presenting in a strategic management situation in a free trade environment. Furthermore, the "how" type of research questions indicated in chapter two are more likely to lead to case studies, because they are explanatory (Yin, 2003). In this regard, it will help to find the answers for questions like why and how New Zealand's businesses strategically respond to the New Zealand-China FTA. Therefore, a case analysis on two typical companies in the New Zealand natural health products industry will be used to provide the empirical basis for trade policy, and to learn about the impact of the FTA on cross-border trade and investment strategies of individual firms.

Moreover, business environmental opportunities as a result of the FTA are only potential opportunities unless the company can utilize its resources and capabilities to take advantage of them and until the strategic leader decides that it is appropriate to pursue the opportunities. It is thereby important to evaluate business environmental opportunities in light of the firms' strengths and weaknesses based on their resources and capabilities (Thompson \& Martin, 2005). The analysis of New Zealand's natural health products industry in the literature review section presents an assessment of the strengths, weaknesses, opportunities and threats experienced by the sector. After a clear understanding of the industrial environment under the New Zealand-China FTA, the companies' strategic adjustment decisions in response to trade liberalization can 
be explored by applying the competitive strategy framework developed in chapter two.

\subsection{Data Collection}

As a description of a business situation, case studies often involve data collection through multiple sources such as verbal reports, personal interviews and observation as primary data sources (Ghauri \& Gronhaug, 2002). This study comprises case studies based on well-patterned face-to-face interviews which enable the researcher to remove communication barriers and encourage the effective flow of information (Cavana et al., 2001).

The data collection for this study proceeded in two phases. In the first phase, the primary method of data collection is structured interviews. The interviews were conducted with senior managers of the selected firms, who are in charge of the business in China. The interviewees have extensive knowledge of the firm and the industry, and they are familiar with their business operations in the Chinese market. An information sheet (see Appendix B) including the nature and purpose of the research, and requesting participation (see Appendix C) in the study was emailed to the identified managers before the interview was conducted. The duration of each interview was approximately one hour. All interviews were based on the same questionnaire (see Appendix D), and were recorded for data analysis purposes.

Based on a review of the relevant literature the questions address the following issues: (a) Firm characteristics (e.g., size, age, nature of the business, 
international experience), (b) level of international involvement (e.g., nature of involvement, countries served, percent of overseas sales), (c) extent of current interests in China (e.g., market position, priority, strategic planning), (d) perception of the New Zealand-China FTA (e.g., industrial effects, business environmental changes, country specific advantages, strategic decisions and planning), (e) international competitive advantages (e.g., resources, capabilities, competence), and (f) strategic adjustments (e.g., cost or differentiation strategy, strategic alliances, mergers, acquisitions).

In the second phase, appropriate secondary data collected from public sources such as websites, presentations, governmental reports, news, and the like, were analyzed for an understanding of the firms, the sector, the nature of New Zealand-China FTA, and business environmental changes as a result of trade liberalization. This provided basis for the purpose of carrying out the concept, frameworks and viewpoints underpinning the analysis on the data obtained from the interviews.

\subsection{Data Analysis}

Since the data from the interviews were descriptive, this study implemented qualitative analysis based on the experiences of the individual research participants and on the stated meanings they attached to their firms, industry and business environment. Accordingly, the primary patterns of the interview data were identified, examined, categorized, and recombined (Yin, 2003). In the first stage, the tape recordings of what the participants said were transcribed. Details about where the interviewee pauses, speeds up or slows down; which words are 
emphasized were also recorded in order to fully understand what the interviewee was trying to communicate. After that, the information obtained from the tape recordings was compared with similarities and differences, as well as relevance to the findings from the literature review, and then categorized into sections according to the variety of meanings, attitudes, interpretations, and the relevance to each research question (PPL, 2004).

On the other hand, this qualitative research made use of direct quotations from the interview responses (what did the interviewees actually say in responses to the research questions?). In this way, key quotes were added to support the research findings.

\subsection{Sample}

The natural health products industry was selected, because it stands to be influenced more significantly by the New Zealand-China FTA than other industries. On the one hand, China is one of the top five markets for the New Zealand's natural health products exports. With the huge market potential for health products, the FTA is more likely to provide greater opportunities for New Zealand's natural health products companies to expand in the Chinese market. On the other hand, New Zealand's manufactured products exported into China have recently faced very high tariffs, which increased the price to local consumers and therefore limited the market growth in China. Given the phased elimination of tariffs for natural health products planned under the FTA rules, the New Zealand natural health products exporters will see a significant reduction in the cost of trading with China (Briar, 2004; NZMFAT, 2008a). 
Two companies in the New Zealand natural health products industry, namely Company A and Company B, were finally selected for three main reasons. Firstly, they both have presence in overseas markets, and they pay close attention and assign high priority to the Chinese market. Secondly, they have suffered some of the strongest tariff and non-tariff protections with regard to access to the Chinese market prior to the FTA, so it appears that they are most inclined to modify their strategic performance in response to the New Zealand-China FTA. Thirdly, the natural health products industry that reflects high value-adding, technology-intensive manufacturing and internationalizing capacities, is often regarded as critical to New Zealand's national economic well-being (Knight, 1997). Therefore, the research on these two natural health products companies is likely to be more representative for New Zealand's businesses in the exporting industry.

Company A is among the leading natural health product manufacturers in the Australasia region. Over its 100 years history, the company has grown into a recognized market leader in health foods and supplements, and a global exporter distributing a broad range of quality products to around 40 countries including the US, the UK, Singapore, and China. With the health and wellbeing sector performing strongly due to ageing populations and consumers keen to prevent health problems rather than be treated for them, Company A is strongly positioned for further growth in Australasia and beyond.

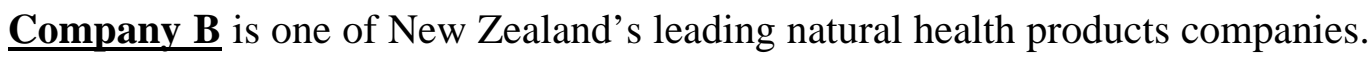
It is proactive in promoting the message of positive health and performance 
through better nutrition, providing ongoing information, innovation and support to its consumers and distribution partners. Today, Company B is a major manufacturer and supplier to the nutritional products market in New Zealand, and currently exports to more than 20 countries including Australia, the UK, Japan, Korea and China. In the fast-growing international health products industry, Company B is strongly positioned to capture the further market growth from the changing lifestyle trends and the increased personal income. 


\section{CHAPTER FOUR: DATA ANALYSIS \&}

\section{RESULTS}

\subsection{Introduction}

The results of the research will be shown in this chapter. In particular, the collected data will be interpreted and analysed through the theories and the conceptual frameworks presented in chapter two. In this way, the chapter discusses case studies of Company A and Company B at a microeconomic level to learn about the strategic decisions made by these firms in adjusting to the new business environment resulting from the New Zealand-China FTA.

\subsection{Case Analysis}

From the review and analysis at the national and industrial levels in chapter two, New Zealand's natural health products companies with limited resources and capabilities are unlikely to be competitive in the Chinese market though they might benefit from certain national or industrial strengths and from an advantage in access to the Chinese market as a result of the New Zealand-China FTA. The case studies here illustrate how some of these companies are seeking to improve or dramatically change their competitive position in the Chinese market as a part of their long-run internationalization process. 


\subsubsection{Company Background}

\subsubsection{Company A}

Company A was founded in Auckland in 1904, and it was originally a flour milling business. Throughout its 100 years history, the company has developed as one of the leading health food and supplement manufacturers in New Zealand. Today, Company A’s annual sales exceed NZ\$50 million and staff number over 250 in offices and plants in New Zealand and Australia. The product range covers more than 750 diverse products and spans many health and wellbeing categories including vitamins and minerals, garlic and herbal supplements, cereals, rice wafers, natural foods and fruit teas. It is not surprising that the majority of New Zealanders rely on Company A's products that are available at almost every supermarket, health food store and pharmacy in the country.

Due to the saturated domestic market, Company A is pursuing an increasing presence in overseas markets. It is marketing a broad range of its unique products from New Zealand to over 40 countries around the world through a worldwide network of distributors and customer partners. Even though the export sales have grown by an average of $15 \%$ per annum in the recent past, the company's international sales have represented less than 40 percent of its total sales. Its businesses have been mainly focused in the Australasia market in recent years. With approximately $90 \%$ of annual revenue generated from Australasia, the company has grown into a market leader in the New Zealand's supplement, functional beverages and healthy foods market, and has built a market leader position in sports nutrition in Australia. 
Company A's success in Australasia reflects its life-long commitment to focus on consumer needs and maintaining a relevant and accessible product portfolio. In order to constantly and effectively satisfy its customers, the company has stringent quality control procedures within the manufacturing, packing and dispatch process in the fully certified Good Manufacturing Process (GMP) ${ }^{6}$ manufacturing facilities. On the other hand, a highly qualified team of technical and research staff with extensive experience and expertise integrates the latest international scientific research with proven and tested natural ingredients. Moreover, regulatory product certification plays a major role in the company's quality control procedures. As well as the GMP registration, certification includes Medicine Licence, HACCP (Food Safety), and Ministry of Agriculture and Forestry certified Meat/Fish Premise, which ensure the products marketed internationally have world-class standards.

\subsubsection{Company B}

In 1984, a New Zealand's food technologist with extensive experience in food technology and strong confidence in the international health food market of the future sets up Company B as a New Zealand-based natural health products company through purchasing a minor Australian business located in New Zealand. Under his management the company has achieved substantial growth, both in the domestic market and the global market over the last two decades. Today, the company has become one of the leading players in New Zealand's

\footnotetext{
${ }^{6}$ Good Manufacturing Practice (GMP) is a term that is recognized worldwide for the control and management of manufacturing and quality control testing of foods, pharmaceutical products, and medical devices. (http://en.wikipedia.org/wiki/Current_good_manufacturing_practice.)
} 
natural health products industry, which employs over 140 staff, has more than 450 product lines, and receives 250 orders on average every day.

From its humble beginnings in 1980s, Company B has moved its operation into high gear. With the opening up of its new 7000 square metre manufacturing and office facility at the end of 2000, the company is aiming to build world-class manufacturing to GMP standards, which is also licensed by Medsafe New Zealand and the Therapeutic Goods Administration in Australia. In addition, the company also holds the licenses from the New Zealand Ministry of Agriculture and Forestry for the manufacture of dairy based powders and specialty powders because a significant part of its business activities involves manufacturing special functional foods based on New Zealand-sourced dairy ingredients and other materials.

The high standards required by these instrumentalities are reflected in Company B's own commitment to deliver quality values. These values are not only shown by the high calibre of its quality assurance programmes, but also by staffinvolved in production and product development. The company has comprehensive traceability systems in place to ensure that every item can be tracked and tested to any point during all stages of production and packaging. As a high technology-based company, Company B also devotes significant resources and efforts to product innovation and development. In order to make sure that the company is at the cutting edge of international trends in the markets in which it operates, the company is always committed to lead the way with innovative and 
effective formulations that are developed by the team of its experienced naturopaths.

As well as its success in New Zealand, Company B has strategically focused on exporting. It has become a major supplier of nutritional products with strong brands in overseas markets such as Australia, the UK, Japan, Korea and China. Considering different market situations, the company markets most of its products through its well-established local customers and distribution partners, mainly health food stores and pharmacy channels in the areas where it operates. Due to the importance of stimulating interest and sales performance in overseas markets, Company B keeps in regular contact with its agents and distributors around the world, and provides ongoing information, innovation and other technical support to them.

\subsubsection{Country Specific Advantages facing Company A \& Company $B$}

To understand the strategic decisions made by Company A and Company B in adjusting to the new trading environment as a result of the New Zealand-China FTA, the vertical axis specifies CSAs (see Figure 2.5) facing the companies which might be either strengthened or weakened by the agreement. These will be analyzed firstly according to the logic of the competitive strategy framework noticed in chapter two.

As mentioned earlier, the international competitive advantages of the companies in different industries may reflect the comparative advantages of nations embedded in them. In other words, the companies of a particular nationality may 
have a certain advantage or competitive edge over those of other nationalities. Similarly, the underlying comparative advantages of both New Zealand and China and the bilateral trade relationship between two countries may provide Company A and Company B with competitive advantages at certain links of their value-added chain as, for example, in research and development (R\&D), manufacturing, and/or distribution.

As New Zealand-based natural health products manufacturers and exporters, Company A and Company B benefit from New Zealand's ideal climatic and environmental conditions, outstanding science, world-leading edge biotechnology research and innovative applications, as well as a track record of supplying quality products. In New Zealand, particularly, the natural health products sector has stimulating levels of innovation and new product development which are supported by the highest proportion of government research and development funding of any OECD countries as well as a wealth of scientific research activities conducted by many international-recognized research institutes and universities. Moreover, the sector operates under worldclass regulatory safeguards to maintain the highest quality of products, monitoring by national authorities such as Medsafe New Zealand and New Zealand Food Safety Authority. Last but not least, the sector enjoys a burgeoning venture capital scene and strong international linkages, which benefit from New Zealand's excellent trading environment. Together all of these strengths constitute the impressive CSAs that allow New Zealand's natural health products companies such as Company A and Company B to successfully market a wide variety of superior natural health products in the global market. 
From the perspectives of Company A and Company B, the competitive strengths derived from those comparative advantages of New Zealand may become unsustainable as they compete with rivals from countries (e.g. Australia) that have very similar situations in the natural health products sector. Fortunately, the New Zealand-China FTA offers Company A and Company B greater opportunities to expand their businesses in China through a CSA via access to the Chinese market. From this point of view, the phased trade liberalization is strengthening the CSAs of two companies, and thus shifting them even further to top half of Figure 2.5.

Based on the New Zealand-China FTA provisions, The Chinese government agrees to eliminate tariffs on 96 percent of the New Zealand current exports to China within the implementation period. Particularly, tariffs on most food products will be phased out over the next 5 or 6 years. Some product tariffs included in China's sensitive category will be removed over 9 years. China considers that there is some domestic sensitivity about some export products, in areas where the Chinese industry is developing. However, these products combined only account for 4 percent of New Zealand's current exports to China. From the interests of New Zealand's natural health products sector, some of the exporting products such as dairy-based powders could be affected. In this regard, Company A and Company B will gain a cost advantage over their international rivals trading with China as increased exports in response to tariff liberalization generating duty savings on a cumulative basis. Thereby “we continue to increase our exports to China. To take advantage of the FTA, we need to fully understand the rules under the agreement through relevant conferences or seminars held by 
New Zealand government.” said the North Asian market manager of Company B.

In the area of investment, the FTA also ensures that Company A and Company B remain competitive with investors from other countries due to the measures that provide enhanced security for investments created in China. "In the long term, we are looking for different investment opportunities in China. China has better resources such as cheaper labour. By manufacturing in China, we are able to lower production costs, but we have to control the product quality.” said the marketing manager of Company A.

On the other hand, the companies will also benefit from provisions to facilitate the travel of business people to China and from access to skilled workers from China in certain occupations where long-term skill shortages exist. "We have many Chinese people in the management positions, because they better understand business conditions and market knowledge of China. We often attend business conferences in cities such as Beijing, Shanghai, and Guangzhou. The company often makes donations to orphanages and schools in China. We donated money and products to the people suffering in the Sichuan Earthquake last year. It helps us to build good brand image in China through our contribution to the society” said the North Asian market manager of Company B

\subsubsection{Strategic Adjustments by Company A \& Company B}

Although they enjoy strong CSAs derived from New Zealand's comparative advantages and trade liberalization, it is quite difficult for Company A or 
Company B, as an individual business, to attain a competitive position in the Chinese market, which is also looked at covetously by numerous powerful MNEs from all over the world. To be more internationally competitive, much of the adjustment needs to be done within the company. Trade liberalization provides an incentive for Company A and Company B to specialize their production and increase their economies of scale, so that their products are produced for China as the Chinese customers are increasingly looking for products that are tailored to their needs at the same time while they are often admiring Western products. "Our products sold in the Chinese market are specially developed. Before we launch our products into China, we need to fully understand the local needs. Due to different country conditions, we have to develop something specific for the Chinese customers, in terms of product formula, packaging and the like.” said the North Asian market manager of Company B.

In terms of the competitive strategy framework, they must move further to the left of the horizontal axis of Figure 2.5. Securing access to the Chinese market will allow them to enhance their FSAs in the areas of cost and differentiation competitiveness. With the globalization and consolidation of the natural health products industry, the only means for the New Zealand practitioners like Company A and Company B with smaller resources and capabilities to ensure long-term sustainable development and expansion are through forming a larger group to leverage market power and hence achieve market growth.

In 2006, Company A and Company B were successively acquired by Next Capital that is an independent private equity company specialising in providing 
capital for later-stage expansion and small-to-mid market buyouts. Next Capital invested around NZ\$25 million and NZS20 million separately in the two companies, aiming to set up a leading group of manufacturing and marketing natural health products companies in Australasia and beyond. Following the acquisitions, Company A and Company B are wholly owned subsidiaries of the same group in which Next Capital holds a 70.7\% stake. The founder of Company B holds $19.9 \%$ and the management of two companies hold the balance. In this way, Company A and Company B chose to enter into a strategic alliance for strengthening their international competitiveness, so that they are capable of capitalizing on business opportunities such as trade liberalization within the rapid-growing natural health products sector with a growth focus on Australasia and other emerging overseas markets such as China. "The combined businesses are complementary in the global market for both companies, in terms of manufacturing, facilities, product development and marketing. Two companies are combined together to become a biggest manufacturer, marketer and distributor of natural health products in New Zealand and even in Australasia. The combination strengthens our capabilities to expand internationally, of course, including the emerging Chinese market.” said the marketing manager of Company A.

The consolidation and collaboration between partner firms will not only rationalize assets and reduce costs, but also leverage the complementary resources and capabilities through sharing internal resources including capital, technologies, human resources and/or raw materials, and through collaborating on partners' value-added activities including R\&D, production, marketing, 
distribution, sales and/or services. Taking the case where the complementary production with Company A specializing in functional beverages and healthy foods as well as Company B specializing in supplements and nutritional products, will expand the production efficiencies and product lines of both companies, and thus enable the attainment of sufficient scale economies that can provide lower production costs per unit. "The combined businesses have more than a thousand product lines. In China, we are one company, but two brands. A wider range of products exporting to China help both companies to gain strong market positions there. It is hard to compete in the Chinese market. Competition is high. There are many players in the market from both local and overseas origins. We may have cost advantage against them, benefiting from the reduction of tariffs and our expanded production. We need to learn about the specific demands of the Chinese customers, so that we can decide which products to market into China. We have specific marketing strategy for China.” said the marketing manager of Company A.

In terms of market development in China, Company A began to enter the Chinese market about 10 years ago after being approached by a Chinese distribution company that had a New Zealand office. With 10 years market penetration in China, Company A's health foods such as bovine dairy colostrums have an increasing presence in local groceries and supermarkets by working with a network of 32 sub-distributors. In contrast, Company B is a relatively new entrant in the Chinese market. It began to export its products to China about 2 years ago. Due to the fact that most of its exporting products are health 
supplements and sport nutrition, it sells them through the health food store and pharmacy channels throughout China.

Considering the cost as resource commitment, control as the level of ownership, risk related to the level of resources committed, and the complexity of China's business environment, Company A and Company B's businesses in China heavily rely on the experiences of their local distributors which are familiar with the local market, customs and conventions. As independent merchants, distributors have substantial freedom to buy products, to choose their own customers and to set the conditions of sales and services. This largely facilitates the marketing activities of two companies though they have little control over distribution, sales and services in the local market.

The complementary marketing models with Company A having a strong presence in grocery and supermarket channels and Company B distributing most of its products through the health food store and pharmacy channels will extend their distribution channels with low costs, and thus broaden the market coverage of both companies. Just like the marketing manager of Company A said: "the two companies have different distribution channels and customer partners in various overseas markets. The combination between two companies is good for international market expansion. It allows us to expand more efficiently in the global market.” Furthermore, Company A has extensive experience in operating in China, benefiting from its more than 10 years marketing expertise in dealing with local customers. Company B intends to expand in the Chinese market but lack local market knowledge. As the combined businesses, Company A can help 
Company B in penetrating the Chinese market more efficiently. For instance, two companies can form a coalition for a specific product where Company A can help Company $\mathrm{B}$ with distribution and selling in the Chinese market while Company B can help Company A with R\&D and production.

Given the critical role of innovation and new product development in the natural health products sector that is highly technology-based, it is necessary to unceasingly build on innovative capabilities for Company A and Company B. The strategic alliance allows two companies to share the fixed costs and risks associated with developing new products and processes. In particular, the complementary R\&D facilities and activities allow them to optimize their laboratory processes and to gain access to each other's advanced emerging technologies. Therefore, they are able to better combine technological and market opportunities in order to produce differentiated goods and information that convey competitive advantages.

To gain a competitive market position in the Chinese market, there is a need to customize production and marketing to meet local needs because of the complexity of the business environment and the fact that Chinese customers increasingly looking for products that are tailored to their desires. Encouraging levels of innovation and new product development as well as a strong market orientation will enable Company $\mathrm{A}$ and Company $\mathrm{B}$ to generate product advantages such as unique benefits, high quality, attractive price, or innovative features, and thereby to satisfy consumer's continuously changing requirements and preferences. 
By approaching a strategic alliance from a perspective of collective competition, Company A and Company B are competing in combination in which they build close ties on their resources and capabilities as well as coalitions on value chain activities to strengthen their competitive positions in the global market. Figure 4.1 shows the process of strategic adjustments by Company A and Company B in response to the new business environment arising from the New Zealand-China FTA. As is shown, the alliance allows Company A and Company B to have separate but complementary competences at each end of the value chain. On the one hand, two companies can share the actual performance of each value chain activity. For example, joint production allows the companies to integrate capital and existing facilitates to gain scale economies or increase the use of facilities, therefore reducing manufacturing costs. Another example is that building collaboration on the technical expertise of Company A and Company B in R\&D that is technologically beyond the capability of the companies operating independently enables them to develop and diffuse new products or technologies rapidly. On the other hand, the alliance allows Company A and Company B to divide and rejoin the value chain activities between themselves. For example, the companies can serve the market quickly and effectively through capitalizing on the manufacturing skills of one company and the marketing skills of the other. 


\section{Figure 4.1 Strategic Adjustments by Company A and Company B}

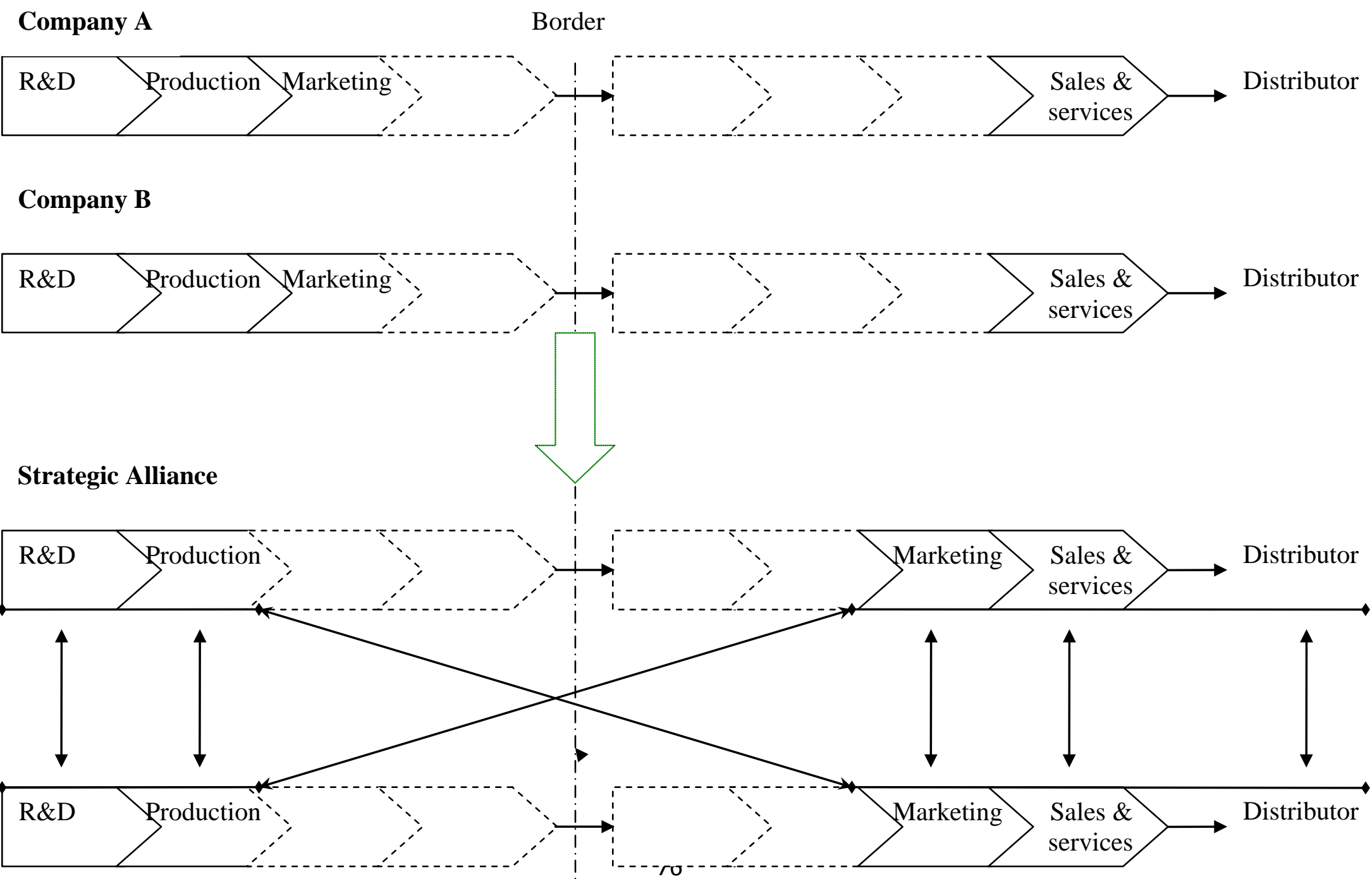

Source: Adapted from Hollensen, 2007, p292. 
In a word, the strategic alliance allows Company A and Company B to build on innovative capabilities and overcome weaknesses, such as pooling financial capital or low levels of expertise in $R \& D$, marketing or distribution, and thereby increase their FSAs over competitors. In this way, they are capable of taking advantage of the New Zealand-China FTA and gaining stronger market positions in China. As they are shifting towards to quadrant 1 of Figure 2.5, Company A and Company $\mathrm{B}$ maximize the strategic benefits of the combination between FSAs held by the integrated businesses and CSAs benefiting from New Zealand's comparative advantages and trade liberalization. The combined businesses allow them to translate these FSAs and CSAs into cost and differentiation advantages which ensure their competitiveness in the global market. 


\section{CHAPTER FIVE: DISCUSSION,}

\section{IMPLICATIONS \& RECOMMENDATIONS}

\subsection{Summary of Research Findings}

Building on an explanation of bilateral trade and economic relationships between New Zealand and China, analysis of the New Zealand-China FTA's impact upon the New Zealand natural health products industry in general, as well as on Company A and Company B in particular, this research explored a number of the tips on strategic decisions made by New Zealand's natural health products companies in adjusting to the changing business environment arising from trade liberalization. In this section, the research results are discussed, and bring together the literature and the key findings from the case studies in an effort to provide responses to the research questions.

In the first place, conceptual and empirical evidence suggests that trade liberalization may lead to a shift in business strategies by firms in any dynamic industries, because of the changing business environment reflected by increasing market opportunities and competitive pressures as a result of easing market restrictions across borders. A firm's choice to react to an FTA strategically is dependent on perceived importance of the FTA to the firm's international strategic development. In other words, the strategic adjustments take place in the context of the firm's long-term strategic plan and seek to strengthen or dramatically change its competitive position in particular markets it operates. Under the New Zealand-China FTA, the Chinese fast-growing market with huge 
potential for healthy products is typical of the mix of the opportunities and challenges facing New Zealand's natural health products companies. The FTA provides them with a strong incentive to undertake strategic adjustments for further development in the Chinese market.

On the other hand, strategic adjustments made by a firm depend upon the nature of its FSAs and CSAs, as well as its existing competitive advantages. Firms that are capable of securing the resources and capabilities necessary to exploit opportunities and counter threats are more likely to gain competitive advantages. Under free trade, international competitiveness is assured when firms are able to maximize the strategic benefits of a combination of FSAs held by them and CSAs derived from the comparative advantages of home and host nations and from trade liberalization.

New Zealand's natural health products sector enjoys strong CSAs as reflected in such factors as ideal climatic and environmental conditions, outstanding science, world-leading edge biotechnology research and innovative application, as well as a track record of supplying quality products. Combined with a fresh CSA with regard to access to the Chinese market, there will be great opportunities for the New Zealand natural health products companies to expand into the Chinese market. However, the opportunities are only potential opportunities unless the firms are able to use their resources and capabilities to take advantage of them. For most of New Zealand's natural health products companies which lack sufficient resources and capabilities for international expansion, therefore, 
finding a way to strengthen their FSAs is the key to gain competitive position in the Chinese market.

Last but not least, smaller firms are more likely to engage in the formation of strategic alliances in order to strengthen their competitive positions both domestically and internationally. Many such firms have inadequate resources and capabilities available to achieve market growth internationally. Strategic alliances represent an expedient way for them to gain competitive advantages through access to a partner's resources such as capital, technologies, information, and raw materials, and capabilities such as skills, market knowledge, and managerial know-how, as well as through collaboration on value chain activities such as R\&D, production, marketing, and distribution.

In New Zealand's natural health products sector, firms are usually small to medium-sized. They are largely under financed and operating with extremely high costs relating to $R \& D$, compliance and regulatory issues. Most of them are unable to effectively and efficiently capitalize on increased market opportunities arising from the New Zealand-China FTA. Appropriate strategic alliances between these firms will allow them the take advantage of trade liberalization and lead to further development in China's fast-growing health products market.

\subsection{Implications and Recommendations}

\subsubsection{Managerial Implications and Recommendations}

The research findings suggest a number of implications for international strategic management practice. First of all, marketing managers in New Zealand-based 
international companies appear to pay close attention to the Chinese emerging market as a result of slowing economic growth in the US and Europe. For New Zealand's businesses, China represents both opportunities and challenges. The opportunities arise from rapid economic growth in the world's largest market and the ongoing maturity of the bilateral trade and investment relationships between New Zealand and China. The challenges arise because of China's complex, diverse and fast-changing business environment with intensified competition from global players. To take advantage of these opportunities and achieve stronger market position in the Chinese marketplace, New Zealand's businesses must become adept at understanding the opportunities and threats created by shifts in the business environment along with the implementation of the New Zealand-China FTA.

Furthermore, New Zealand's businesses in some sectors (e.g. agriculture and natural health products) benefit from strong competitive advantages derived from New Zealand's comparative advantages against foreign rivals. The image New Zealand projects as part of Tourism New Zealand’s “100\% Pure New Zealand” promotion, for example, is a good source of competitive advantage for numerous industries to compete internationally, as products or services from countries with a positive image tend to be favourably evaluated. Firms in these sectors should use those CSAs that could be beneficial to their operations in the pursuit of their strategic objective. And they must continuously build up their own capabilities in internalizing those advantages, and exploit them to create sustainable value. In addition to comparative advantages from the home country, bilateral trade and investment liberalization with China allows New Zealand's businesses to obtain 
international competitiveness from China's comparative advantages such as a cheap manufacturing base. Through investing in China, New Zealand's businesses can take advantage of vertical integration brought by the complementary comparative advantages of both nations (i.e. lower production costs).

On the other hand, many of businesses in New Zealand, especially the small and medium enterprises (SMEs) lack adequate resources and capabilities for international market growth. In other words, it is more difficult for them to take advantage of the market access opportunities arising from the New ZealandChina FTA. They must develop market penetration strategies on the basis of their respective or joint competitive advantages. In this context, various sorts of strategic alliances with suitable domestic businesses appear to be increasingly used by these firms to maintain or improve their competitive position together in the Chinese market. The case studies in this research suggest that managers must consider forming a strategic alliance from the perspective of collective competition. They should attain clarity on the company's core competences and capabilities, and evaluate possible strategies to match them with those of the potential partners. The aim is to create an alliance in which resources and capabilities of each partner are compatible and complementary, not necessarily identical. In addition to carefully select suitable alliance partners, making alliances work requires building trust and interpersonal relationships between partners and taking proactive steps to learn from each other. 
In order to better take advantage of the New Zealand-China FTA, New Zealand's businesses may need to seek engagement in cross-border alliances with local businesses that understand business conditions and have good connections in local markets. New Zealand's natural health products companies, for example, should pursue alliances with local partners to set up their own distribution networks and even, in some cases, their own manufacturing facilities in China, in order to avoid barriers such as differences in local regulatory requirements, medical practices and customer demand. Although forming alliances with local partners represent a desirable option for many New Zealand firms to enter or expand into the Chinese market, managers may face potential challenges in terms of communication and cooperation. Fonterra's recent failure in their joint venture with San Lu would be a good lesson for New Zealand's managers in approaching a collaborating partnership with local businesses in China.

\subsubsection{Theoretical Implications and Recommendations}

This study mainly exploits two streams of literature: trade policy and international strategic management. The theoretical research on regional economic integration has been undertaken for the purpose of providing the concepts and viewpoints underpinning the research on international strategic management. Based on case studies investigating how New Zealand's natural health products companies strategically respond to the New Zealand-China FTA, this research provides the empirical basis for understanding the interactive nature of global strategic decision-making and trading environment, and for understanding sources of international competitiveness. 
The research findings emphasize the importance of the attainment of an appropriate match between a firm's strategic performance and the trading environment in which it operates in its long-term internationalization process. A strategic perspective explores how changes in the trading environment generate both opportunities and threats to which firms must respond. To take advantage of the opportunities and neutralize the threats, firms need to deliver sustainable competitive advantages that can be gained by effectively implementing strategies that exploit internal strengths and avoid internal weaknesses against competitors both domestic and international. As discussed earlier, this is a relatively new area, only recently being researched from economic and political interests. Accordingly, these research findings may offer significant theoretical and empirical contributions to the existing studies concerning trade policy and international strategic management performance.

Since they are strategic actors in the global business environment, most research on international strategic management focuses on MNEs. In keeping pace with a rapid-changing environment, however, SMEs are more likely to make strategic adjustments in order to seek opportunities and neutralize threats, as they increasingly engage in global business activities. Compared with large multinationals, smaller firms are more desirous and flexible to strategically react to those business environmental changes. From this perspective, this study also contributes to the research area on internationalization of SMEs by providing an understanding of how SMEs strategically maintain or improve their competitiveness in the global marketplace. 
In addition, many strategic models have been developed in the research field of strategic management (e.g. SWOT Analysis, BCG Matrix ${ }^{7}$, and Porter's five forces analysis). These theoretical frameworks can help to make logical sense of the relationships of the variables and factors that has been deemed relevant or important to the problem, and/or to provide a systematic view of a phenomenon by collecting interrelated concepts which guide research and practice (Liehr \& Smith, n.d.). For instance, the competitive strategy framework discussed in chapter two (see Figure 2.5) does well combining factors particular to the firm and the country (i.e. FSAs and CSAs) with three main strategic concepts (i.e. Porter's three generic strategies), which creates the knowledge base to assess the international competitive position of the business entities and predict their strategic performance in adjusting to trade liberalization. In addition, the framework built on the research results (see Figure 4.1) conceptualizes the strategic adjustment decisions made by Company A and Company B in response to the New Zealand-China FTA, which may help managers in formulation and implementation of their business strategies in adjusting to free trade.

Building on the application of these analytical frameworks, this research makes significant theoretical contributions to the academic community by creating a repertoire of knowledge which enables evaluation and development of the frameworks for use in future research.

Apart from contributions to the academic world, this research has a number of limitations. Firstly, the sample base was comprised of selected manufacturers

\footnotetext{
${ }^{7}$ The BCG matrix method is based on the product life cycle theory that can be used to determine what priorities should be given in the product portfolio of a business unit. (http://www.valuebasedmanagement.net/methods_bcgmatrix)
} 
exporting to China in a large, up-to-date directory of New Zealand-based firms that engage in international operations. With a small response rate, however, the research is finally based on case studies of two companies in a given industry. As a result, the research results seem to be not generalized for all New Zealand's businesses. So these is a need for further research on strategic responses to the New Zealand-China FTA by conducting surveys and interviews with numerous firms in a variety of industries in New Zealand.

Moreover, this research only emphasizes small to medium-sized firms. It would be interesting for future research to examine the differences in strategic decisions made by SMEs and MNEs in response to trade liberalization, or the issues about how SMEs expand internationally through strategically collaborating with MNEs.

Last but not least, as countries are inclined to seek high-quality comprehensive FTAs, the modern FTAs in today's business environment do not only traditionally cover trade in goods, services and investment, but also appear to have a set of supporting rules in a broad range of areas, including labour mobility, intellectual property rights, competition policies, and government procurements. This research only considers the New Zealand manufacturing companies' strategic adjustments to trade liberalization in goods and investments. Other measures in FTAs such as intellectual property rights and competition policies may also need to be addressed on the future research in the similar area, because they are likely to affect a firm's international strategic management practice as well. 


\section{CHAPTER SIX: CONCLUSIONS}

In conclusion, this research considers the process of strategic adjustments made by New Zealand's businesses in response to the New Zealand-China FTA. Building on case studies of Company A and Company B in the New Zealand natural health products industry, the research discovers the nature of salient company characteristics under a free trade environment, and ascertains the particular patterns of strategic performance which managers will adopt in response to trade liberalization.

Under the agreement, New Zealand and China agree to liberalize and facilitate trade in goods, services and investment, as they have been committed to build up longstanding and healthy bilateral trade and economic partnership. From the perspective of New Zealand's businesses, the FTA will improve the business environment and open up market access opportunities for them. To take advantage of these opportunities and hence achieve a stronger market position in the Chinese fast-growing market, New Zealand's businesses must become adept at understanding the opportunities and threats created by shifts in the freer trade environment, as well as their internal strengths and weaknesses. Building on their knowledge of external opportunities and threats in light of internal strengths and weakness, they are more capable of making strategic adjustments (e.g. strategic alliances) to maximize the strategic benefits of the combination between FSAs held by themselves and CSAs benefiting from New Zealand's comparative advantages and trade liberalization, and translate them into cost and 
differentiation advantages which ensure their competitiveness with respect to foreign rivals.

The findings of this study will be of great value to academic and government communities, and business practitioners. Politicians can utilize the research findings in creation or modification of the trade and economic regulations from which local businesses profit. Moreover, the study also provides valuable information and reference for scholars to undertake a thorough, penetrating and evaluative analysis of the relevant topics in the academic field. More importantly, the results of this research will assist New Zealand's businesses in developing their own capabilities and strategies to operate in today's fast-changing business environment. 


\section{REFERENCES}

Acharya, R., \& Daly, M. (2004). Selected issues concerning the multilateral trading system. Retrieved July 12, 2008, from: http://www.wto.org/english/res_e/booksp_e/discussion_papers7_e.pdf.

Akoorie, M. E. M., \& Scott-Kennel, J. (2005). International business strategy: a New Zealand perspective. Auckland: Pearson Education New Zealand.

Armengol, M. O., McKay, J., \& Pineau, G. (2005). Regional economic integration in a global framework. Frankfurt: European Central Bank.

Baird, I. S., Lyles, M. A., \& Orris, J. B. (1994). The choice of international strategies by small businesses. Journal of Small Business Management, 32(1): 48-59.

Balassa, B. (1961). The theory of economic integration. London: Allen \& Unwin.

Barney, J. (1991). Firm resources and sustained competitive advantage. Journal of Management, 17(1); 99-120

Barney, J. (2007). Gaining and sustaining competitive advantage. NJ, USA: Pearson Prentice Hall.

Bas, C. L., \& Sierra, C. (2002). Location versus home country advantages in R\&D activities : some further results on multinationals’ locational strategies. Research Policy, 31(4): 589-609. 
Briar, R. (2004). Overview and strategic development of the New Zealand natural products industry. NZ Natural Products Industry Group.

Campbell, A. J. (1996). The effects of internal firm barriers on the export behaviour of small firms in a free trade environment: evidence from NZFTA. Journal of Small Business Management, 34(3): 50-58.

Cavana, R. Y., Delahaye, B. L., \& Sekaran, U. (2001). Applied business research: qualitative and quantitative methods. Milton: John Wiley \& Sons Australia, Ltd.

Cavusgil, S. T., Knigh, G., \& Riesenberger, J. R. (2008). International business: strategy, management, and the new realities. New Jersey: Pearson Prentice Hall.

Connor, T. (2002). The resource-based view of strategy and its value to practicing managers. Strategic Change, 11(6): 307-316.

Crawford, J.-A., \& Fiorentino, R. V. (2005). The changing landscape of regional trade agreements. Retrieved October 8, 2008, from: http://www.wto.org/english/res_e/booksp_e/discussion_papers7_e.pdf.

Czinkota, M. R., \& Ronkainen, I, A. (1997). International business and trade in the next decade: report from a Delphi study. Journal of International Business Studies, 28(4): 827-844.

Daly, M, J., \& Rao, P, S. (1986). Free trade, scale economies and productivity growth in Canadian manufacturing. The Manchester School, 54(4): 391402. 
Derosa, D, A. (1998). Regional integration arrangements: static economic theory, quantitative findings, and policy guidelines. Retrieved July 8, 2008, from: http://www.worldbank.org/html/dec/Publications/Workpapers/wps2000se ries/wps2007/wps2007.pdf.

Ersson, M., \& Tryggvason, J. (2007). Internationalization of Nordic Banks: two case studies. Retrieved February 10, 2009, from: http://epubl.ltu.se/14021552/2007/018/LTU-DUPP-07018-SE.pdf.

Etemad, H., \& Wright, R. W. (1999). Internationalization of SMEs: management responses to a changing environment. Journal of International Marketing, 7(4): 4-10.

Fahy, J., \& Smithee, A. (1999). Strategic marketing and the resource based view of the firm. Academy of Marketing Science Review, 1999(10): 1-20.

Farrell, D., Gersch, U., \& Stepthenson, E. (2006). The value of China’s emerging middle class. Serving the new Chinese consumer (2006 special ed). New York: McKinsey \& Company.

Fergusson, I, F. (2008). World trade organizations: the Doha development agenda. Retrieved July 10, 2008, from: http://www.italy.usembassy.gov/pdf/other/RL32060.pdf.

Feridhanusetyawan, T. (2005). Preferential trade agreement in the Asia-Pacific region. Retrieved August 2, 2008, from: http://papers.ssrn.com/sol3/Delivery.cfm/wp05149.pdf?abstractid=88801 $\underline{8 \& \operatorname{mirid}=4}$. 
Fiorentino, V. R., Verdeja, L., \& Toqueboeuf, C. (2006). The Changing landscape of regional trade agreements: 2006 update. Geneva: WTO.

Fisher, G., Hughes, R., Griffin, R., \& Pustay, M. (2006). International business: managing in the Asia-Pacific. Frenchs Forest, N.S.W. : Pearson Education Australia.

Fung, K. C., Lizaka, H., \& Tong, S. (2002). Foreign direct investment in China: policy, trend and impact. Retrieved February 16, 2009, from: http://www.hiebs.hku.hk/working_paper_updates/pdf/wp1049.pdf.

Ghauri, P., \& Gronhaug, K. (2002). Research methods in business studies: a practical guide ( $2^{\text {nd }}$ ed). Harlow: Pearson Education Limited.

Gibson, J. K., \& Harris, R. I. D. (1996). Trade liberalization and plant exit in New Zealand manufacturing. The Review of Economics and Statistics, 78(3): 521-529.

GTN. (2004). Regionalism summary. Global Trade Negotiations. Retrieved July 8, 2008, from: http://www.cid.harvard.edu/cidtrade/issues/regionalism.html.

Hill, C. W. L. (2005). International business: competing in the global marketplace. New York, McGraw-Hill/Irwin.

Hodgson, A. (2007). China’s middle class reaches 80 million. Retrieved February 22, 2009, from: www.euromonitor.com/Chinas_middle_class_reaches_80_million. 
Hollensen, S. (2004). Global Marketing: a decision-oriented approach. Essex: Pearson Education Limited.

Jaffe, E. D., \& Nebenzahl, I. D. (2001). National image and competitive advantage: the theory and practice of country-of-origin effect. Copenhagen: Copenhagen Business School Press.

Johnson, G., Scholes, K., \& Whittington, R. (2006). Exploring corporate strategy: text and cases (Enhanced media edition). New York: Prentice Hall.

Julien, P. A., Joyal, A., \& Deshaies, L. (1994). SMEs and international competition: Free trade agreement or globalization? Journal of Small Business Management, 32(3): 52-64.

Knight, G. A. (1997). Firm orientation and strategy under regional market integration: a study of Canadian firms. The International Executive, 39(3): 351-374.

Lee, Y, S. (2006). Bilateralism under the World Trade Organization. Northwestern Journal of International Law \& Business, 26(2): 357-371.

Li, S. (2004). Location and performance of foreign firms in China. Management International Review, 44(2): 151-169.

Liehr, P., \& Smith, M. J. (n.d). Frameworks for research. Retrieved April 7, 2009, from:

http://homepage.psy.utexas.edu/HomePage/Class/Psy394V/Pennebaker/R eprints/Liehr\%20Class.doc. 
Miyagawa, M., Maniar, S., Umehara, K., Keong, P. K., \& Mikuriya, K. (2000). Japan-Singapore Economic Agreement for A New Age Partnership. Retrieved October 10, 2008, from: http://www.mof.go.jp/jouhou/kanzei/ka140115b2.pdf

Morrison, W.M. (2007). China's economic conditions. Congressional Research Service Report for Congress (order code RL33534). Washington, DC: The Library of Congress.

NBSC. (2007). China statistics yearbook. Bei Jing: National Bureau of Statistics of China. Retrieved February 16, 2009, from: http://www.stats.gov.cn/tjsj/ndsj/2007/indexeh.htm.

NPNZ. (n.d.). About natural products NZ. Blenheim: Natural Products NZ. Retrieved February 18, 2009, from: http://www.naturalproductsnz.org/about.htm.

NZBIO. (2008). Bio international convention 2008: New Zealand biotechnology overview. Wellington: NZBIO. Retrieved February 20, 2009, from: www.nzbio.org/bio2008.

NZMFAT. (2004). A joint study report on a free trade agreement between China and New Zealand. Wellington: New Zealand Ministry of Foreign Affair and Trade. Retrieved February 15, 2009, from: http://www.mfat.govt.nz/Trade-and-Economic-Relations/0--Tradearchive/0--Trade-agreements/China/0-execsummary.php. 
NZMFAT. (2007). A basic guide to free trade agreements: ten questions and answers about free trade agreements. ISBN: 0-447-03797-8. Wellington: New Zealand Ministry of Foreign Affair and Trade.

NZMFAT. (2008a). New Zealand-China Free Trade Agreement. Wellington: New Zealand Ministry of Foreign Affair and Trade.

NZMFAT. (2008b). Background information about the NZ-China FTA. New Zealand-China Free Trade Agreement. Wellington: New Zealand Ministry of Foreign Affair and Trade. Retrieved July 7, 2008, from: http://www.mfat.govt.nz/Trade-and-Economic-Relations/TradeAgreements/China/index.php.

NZMFAT. (2009). New Zealand-China Free Trade Agreement. Wellington: New Zealand Ministry of Foreign Affair and Trade. Retrieved February 18, 2009, from: http://www.mfat.govt.nz/Trade-and-EconomicRelations/Trade-Agreements/China/index.php.

NZTE. (2005). Biotechnology, agritech and natural products: sector engagement strategy. Wellington: New Zealand Trade and Enterprise. Retrieved February 25, 2009, from: http://www.aucklandplus.com/shadomx/apps/fms/fmsdownload.cfm?file uuid=DE6711E5-BCD4-1A24-9E8B$\underline{\text { F13B7BDCE021\&siteName=subsites. }}$.

NZTE. (2006a). New Zealand's health ingredients \& functional foods industry. Wellington: New Zealand Trade and Enterprise. Retrieved February 20, 2009, from: 
www.investmentnz.govt.nz/common/files/Functional\%20Foods\%20Mark eting\%20Doc_Final.PDF.

NZTE. (2006b). Unique opportunities highlighted in new function foods report. Wellington: New Zealand Trade and Enterprise. Retrieved February 20, 2009, from: www.investmentnz.govt.nz/section/14237/15127.aspx.

NZTE. (2008). Navigating China for New Zealand businesses. Wellington: New Zealand Trade and Enterprise.

Pal, P. (2004). Regional trade agreements in a multilateral trade regime: an overview. Retrieved on April 10, 2008, from: http://www.networkideas.org/feathm/may2004/survey_paper_RTA.pdf.

Patel, P., \& Vega, M. (1999). Patterns of internationalization of corporate technology: location vs home country advantages. Research Policy, 28(23): $145-155$.

Patterson, P., \& Tai, S. (1991). Consumer perceptions of country of origin in the Australian Apparel Industy. Marketing Bulletin, 2: 31-40.

Pearce, J. A., \& Robinson, R. B. (2007). Formulation, implementation and control of competitive strategy. New York: McGraw-Hill/Irwin.

Phatak, A. V., Bhagat, R. S., \& Kashlak, R. J. (2005). International management: managing in a diverse and dynamic global environment. New York: McGraw-Hill/Irwin. 
Piercy, N. F. (1981). Company internationalization: active and reactive exporters. European Journal of Marketing, 15(3): 26-44.

Porter, M. (1985). Competitive advantage: creating and sustaining superior performance. New York: Free Press.

Porter, M. E., (2000). Location, competition, and economic development: local cluster in a global economy. Economic Development Quarterly: 2000, 14(1): 15-34.

PPL. (2004). Research methods: data anylysis. New York: Psychology Press Ltd. Retrieved February 20, 2009, from: http://www.psypress.com/pip/resources/chapters/PIP_S3.pdf.

Roth, K. (1992). International configuration and coordination archetypes for medium-sized firms in global industries. Journal of International Business Studies, 23(3): 533-549.

Rugman, A. M. (1986). The role of multinational enterprises in US-Canadian economic relations. Columbia Journal of World Business, 21(2): 15-27

Rugman, A. M., \& Gestrin, M. (1993). "The strategic response of multinational enterprises to NAFTA." Columbia Journal of World Business, 24(4): 1829.

Rugman, A. M., \& Verbeke, A. (1990). Global corporate strategy and trade policy. London/New York: Routledge. 
Ryan, J. (2008). The Finnish country-of-origin effect: the quest to create a distinctive identity in a crowded and competitive international marketplace. Journal of Brand Management, 16(1-2): 13-22.

Shan, W., \& Hamilton, W. (1991). Country-specific advantage and international corporation. Strategic Management Journal, 12(6): 419-432.

Siddharthan, N. S., \& Lakhera, M. L. (2005). Foreign direct investment and location advantages: Japanese perceptions of India compared to China and ASEAN. Journal of International and Area Studies, 12(1): 99-110.

Skilling, D., \& Boven, D. (2006). Competing to win: an external strategy for a changed world. Discussion Paper 2006/3. Auckland: The New Zealand Institute.

STATSNZ. (2008). Global New Zealand international trade, investment and travel profile. Wellington: Statistics New Zealand. Retrieved February 15, 2009, from www.stats.govt.nz/products-and-services/global-newzealand.

Tallon, M. J. (2008). Nutraceuticals in China and Japan: emerging opportunities and their crossover potential for Western markets. Retrieved February 25, 2009, from: http://www.reportbuyer.com/pharma_healthcare/dietary/nutraceuticals_ch ina_japan.html.

Thompson, J., \& Martin, F. (2005). Strategic management: awareness and change ( $5^{\text {th }}$ ed). London: Thomson Learning. 
Tong, C, H., \& Tong, L, I. (2007). America’s regional and bilateral free trade agreements. Competition Forum, 5(1): 48-52.

Valentin, E. K. (2001). SWOT analysis from a resource-based view. Journal of Marketing Theory and Practice, 9(2): 54-69.

Villareal, M, A. (2005). Trade integration in the Americas. Retrieved July 10, 2008, from:

http://www.usembassy.at/en/download/pdf/trade_americas.pdf.

Viner, J. (1950). The customs union issue. New York: Carnegie Endowment for International Peace.

Westhead, P., Wright, M., \& Ucbasaran, D. (2002). International marketing selection strategies selected by 'micro' and 'small' firms. The International Journal of Management Science, 30: 51-68.

Whalley, J. (2006). China in the world trading system. Economic Studies, 52(2): 215-245.

Wikipedia. (2007). Doha development round. Retrieved July 10, 2008, from: http://en.wikipedia.org/wiki/Doha_Round.

WTO. (2007a). Understanding the WTO. Geneva: World Trade Organization. Retrieved July 10, 2008, from:

http://www.wto.org/english/thewto_e/whatis_e/tif_e/understanding_e.pdf. 
WTO. (2007b). Regional trade agreements: facts and figures. Geneva: World Trade Organization. Retrieved July 10, 2008, from: http://www.wto.org/english/tratop_e/region_e/regfac_e.htm.

Xin, Z. G. (2004). Dissecting China’s 'middle class’. Retrieved February 22, 2009, from: www.chinadaily.com.cn/english/doc/200410/27/content_386060.htm.

Xinhua. (2008a). China, New Zealand sign FTA pact. Retrieved February 18, 2009, from: http://news.xinhuanet.com/english/200804/07/content 7933330.htm.

Xinhua. (2008b). Interview: Clark says China-NZ FTA “significant achievement”. Retrieved February 18, 2009, from: http://news.xinhuanet.com/english/2008-04/07/content_7935154.htm.

Yang, Q., \& Jiang, C. X. (2007). Location advantages and subsidiaries’ R\&D activities in emerging economies: exploring the effect of employee mobility. Asia Pacific Journal of Management, 24(3): 341-358.

Yin, R. K. (2003). Case Study Research, Design and Methods. CA: Sage Publications.

Zahrnt, V. (2005). How regionalization can be a pillar of a more effective World Trade Organization. Journal of World Trade, 39(4): 671-699.

Zhang, Z. (2003). Regional integration, trade and investment expansion in the Asia Pacific. Regional Science, 82(3): 303-307. 


\section{APPENDICES}

\section{Appendix A: SWOT analysis of NZ natural health products industry}

\begin{tabular}{|c|c|}
\hline Strengths & Weaknesses \\
\hline 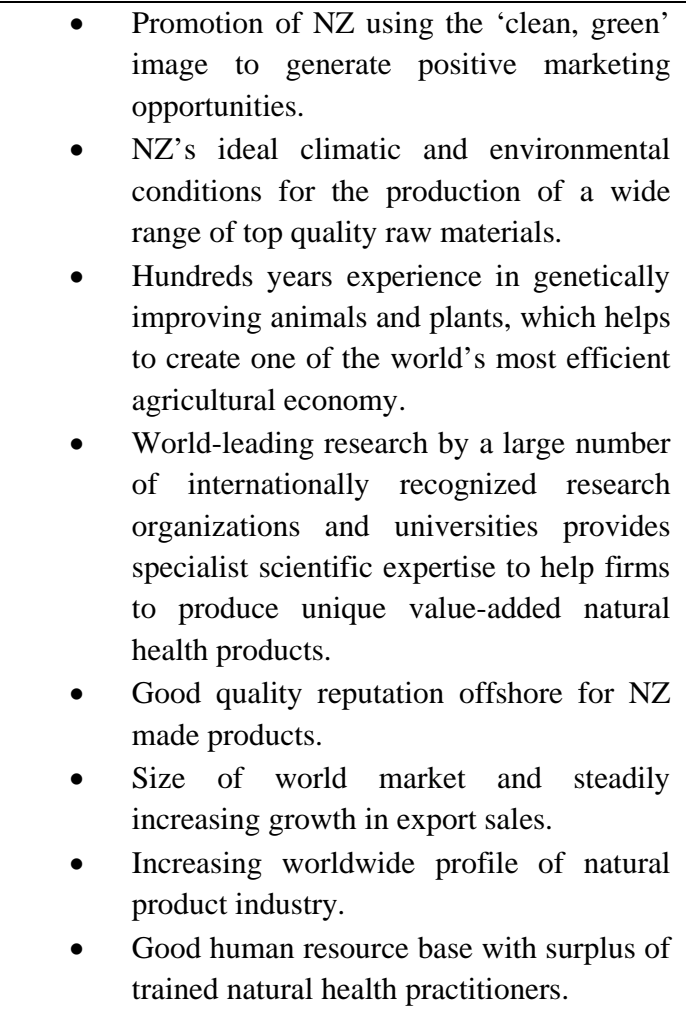 & $\begin{array}{l}\text { - Limited financial resources to expand in } \\
\text { the Chinese market. } \\
\text { - Lower levels of productivity and fewer } \\
\text { resources to capitalize on the increased } \\
\text { exporting opportunities arising from the } \\
\text { NZ-China FTA } \\
\text { - Lack of market knowledge about potential } \\
\text { consumers, competition and business } \\
\text { practices in China } \\
\text { Language and cultural issues }\end{array}$ \\
\hline Opportunities & Threats \\
\hline $\begin{array}{l}\text { - Increased demand for natural health } \\
\text { products and the fast growing purchasing } \\
\text { power in China provide huge export } \\
\text { potentials for NZ-produced/established } \\
\text { branding of NZ's 'clean, green' image. } \\
\text { Growing concerns in global markets about } \\
\text { pollution, environmental contaminants, } \\
\text { leading an increasing desire of natural, } \\
\text { healthy, environmentally-friendly } \\
\text { products. } \\
\text { Bilateral investment arising from the FTA } \\
\text { would take advantage of vertical } \\
\text { integration brought by complementary } \\
\text { comparative advantages of the two } \\
\text { nations' natural health products sectors. } \\
\text { Access to government funding for } \\
\text { research and technical development }\end{array}$ & $\begin{array}{l}\text { - Increased completion from both domestic } \\
\text { and offshore markets. } \\
\text { - Lack of sufficient funds for SMEs to } \\
\text { commission R\&D. } \\
\text { Rapidly increasing costs of regulatory } \\
\text { compliance in the Chinese market } \\
\text { - Food safety issues in China } \\
\text { - Possible stress on trade between China } \\
\text { and the West as well as eroding local } \\
\text { consumer confidence as a result of infant } \\
\text { milk powder contamination happened } \\
\text { early } 2008 \text {. }\end{array}$ \\
\hline
\end{tabular}

Source: Briar, 2004. 


\section{Appendix B: Participant Information Sheet}

TE WHARE WÃNANGA O TE OPOKO O TE IKA A MAUI

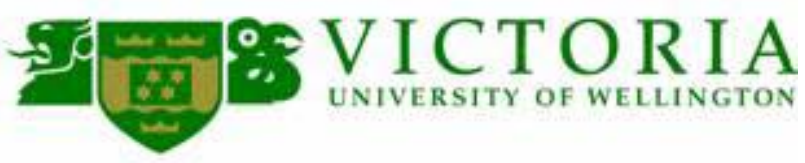

\section{SCHOOL OF MARKETING \& INTERNATIONAL BUSINESS}

P.O. Box 600, Wellington, New Zealand. Telephone + 644 463-5330

Website: $\underline{\text { http://www.victoria.ac.nz/smib }}$

Information Sheet for a Study of "Strategic Responses to New Zealand-

China FTA: a Case Study of New Zealand Natural Health Products

Industry”

Dear,

I am a post-graduate student studying for a Master of Commerce and Administration (MCA) degree at the School of Marketing and International Business in Victoria University of Wellington. To fulfill the requirement of this degree, I have to conduct an empirical research project. Results will be compiled into a written report and deposited in the Victoria University of Wellington library.

The purpose of my research is to examine how New Zealand businesses perceive and strategically respond to the New Zealand-China Free Trade Agreement. The findings of this study would have important implications for scholars and 
managers alike, and especially assist New Zealand businesses in the development of their own capability for the management of business opportunities in China's complex, diverse and fast-changing business environment.

To assist in this research may I confirm an interview with you please? The meeting with you will not be longer than 1 hour in the interests of your busy schedule. I would like to ask a few questions around the themes of my study. In return for your time I will give you a copy of the results of the research, if you request.

The University has granted ethics approval for this research. This is to ensure your interests are protected and that you knowingly consent to help me with my research. What you provide me will form the basis of my research. Your name and your company's name may appear in my completed thesis and any resulting publications (available in the Victoria University of Wellington library). You may always refuse to provide any information you deem too sensitive and you are allowed to withdraw from the research before 31 Jan 2009.

All written material or interview notes will kept in a locked file with access restricted to myself only and will be destroyed three years after the conclusion of the research. Moreover, I will record interviews for information review purpose 
and all audio recordings will be electronically wiped at the conclusion of the research

You will always be free to discuss any questions you may have about this project with me at any time and can contact me by email or phone (details below) or you can contact my supervisors, Joanna Scott-Kennel, Senior lecturer at the School of Marketing and International Business (Email: joanna.scott-kennel@vuw.ac.nz; Phone: 0-4-463 6913 ”available after 20-Jan-09”), and Val Lindsay, Head of School of Marketing and International Business ( Email: val.lindsay@vuw.ac.nz; Phone: 0-4-463 6915).

Your participation in this project will contribute greatly to the completion of my Master degree. I will be very grateful if you will consider participating in the research, and hope to meet you in due course.

Yours sincerely, Jiang Chang

MCA student

School of Marketing and International Business

Victoria University of Wellington

Phone: 021-045 9532

Email: changjian@myvuw.ac.nz 


\title{
Appendix C: Participant Consent Form
}

TE WHARE WÃNANGA O TE OPOKO O TE IKA A MAUI

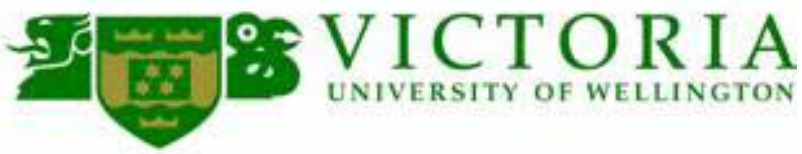

\author{
SCHOOL OF MARKETING \& INTERNATIONAL BUSINESS \\ P.O. Box 600, Wellington, New Zealand. Telephone + 644 463-5330 \\ Website: $\underline{\text { http://www.victoria.ac.nz/smib }}$
}

\section{CONSENT TO PARTICIPATION IN RESEARCH}

Title of the project:

Strategic Responses to New Zealand-China FTA: a Case Study of New

Zealand Natural Health Products Industry

I have been given and have understood an explanation of this research project. I have had an opportunity to ask questions and have them answered to my satisfaction.

I understand that I may withdraw from this project at any time before the deadline (31 Jan 2009) without having to give reasons. 
I understand that once I choose to withdraw from this project, all information I have provided will be destroyed.

I understand that my name and my company's name will not be identified in the publication of this study.

I agree to be taped for the interview.

I understand that the data I provide will not be used for any other purpose except perhaps forming the basis of papers written for conferences or journals. This consent is for no other purpose and the information will not be released to others without my written consent.

I agree to take part in this research.

Signed: Print name:

I would like to receive a summary of the conclusions of this research when it is completed. 
Appendix D: Interview Questions

TE WHARE WĀNANGA O TE OPOKO O TE IKA A MAUI

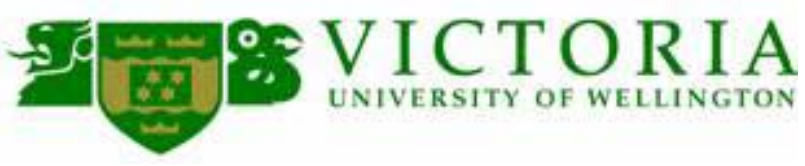

SCHOOL OF MARKETING \& INTERNATIONAL BUSINESS

P.O. Box 600, Wellington, New Zealand. Telephone + 644 463-5330

Website: http://www.victoria.ac.nz/smib

Title of the project:

Strategic Responses to New Zealand-China FTA: a Case Study of New

Zealand Natural Health Products Industry

\section{Descriptive questions}

1. Please describe the nature of your business?

2. How long have you been doing business internationally?

3. What proportion of your total sales comes from foreign business activities?

4. What country markets do you have business in? And which one is the most profitable market?

\section{Specific Research Objective Questions}

5. When did you first enter the Chinese market?

6. Please describe what motivated you to enter the Chinese market? 
7. And can you explain the extent of your current interests in China?

8. In particular to NZ-China Free Trade Agreement

a. What effects do you think it will have on NZ health product industry?

i. For example, any changes in business environment resulting from the agreement?

b. Any opportunities or threats arising especially for your company? (what would you gain or lose from NZ-China FTA)

c. In terms of your international business strategy, especially you business strategy in China, are you cost-focused, product specialization focused, or both?

i. Are you going to change these strategies in response to NZ-China FTA?

- For example, set up your own factory in China to take advantage of a cheap manufacturing base, or differentiate your products to better meet local needs.

ii. What other strategic adjustments have you made or you are going to make in response to those opportunities and threats resulting from the FTA?

iii. What specific resources and capabilities do you have which enable you to make these adjustments?

- For example, financial capital or well-established relationship with local agents 
9. Do you think your company is competitive in the global market, and especially in the Chinese market?

i. What specific areas do you have competitive advantage?

ii. Do you think your products still benefit from New Zealand brand image such as pure and nature in the Chinese market?

- And how?

- In addition to New Zealand brand image, anything else your foreign business can benefit from New Zealand? For example, human resource and raw material.

10. What advice can you offer other NZ businesses planning to enter or expand into the Chinese market?

11. Finally, do you have any questions or anything you would like to add which I have not covered? 